US Army Corps of Engineers ${ }_{\circledast}$

Engineer Research and Development Center

Status of Freshwater Mussels in the Lower Ohio River in Relation to the Olmsted Locks and Dam Project: 1999 Studies

Barry S. Payne and Andrew C. Miller July 2001 
The contents of this report are not to be used for advertising, publication, or promotional purposes. Citation of trade names does not constitute an official endorsement or approval of the use of such commercial products.

The findings of this report are not to be construed as an official Department of the Army position, unless so designated by other authorized documents. 


\section{Status of Freshwater Mussels in the Lower Ohio River in Relation to the Olmsted Locks and Dam Project: 1999 Studies}

by Barry S. Payne and Andrew C. Miller

Environmental Laboratory

U.S. Army Engineer Research and Development Center 3909 Halls Ferry Road

Vicksburg, MS 39180-6199

Final report

Approved for public release; distribution is unlimited 


\section{Contents}

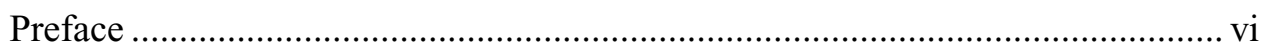

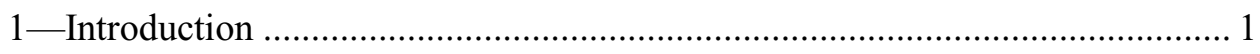

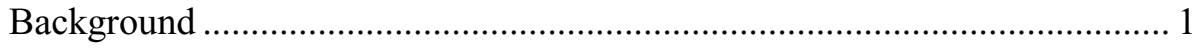

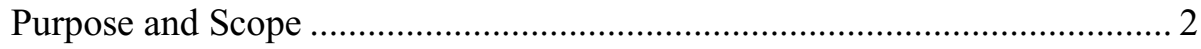

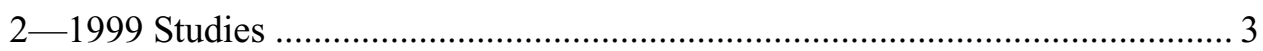

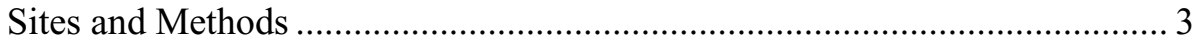

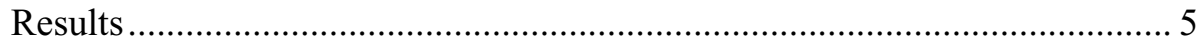

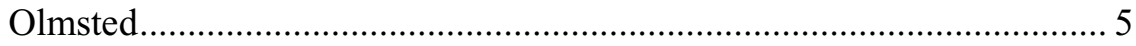

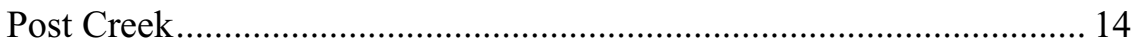

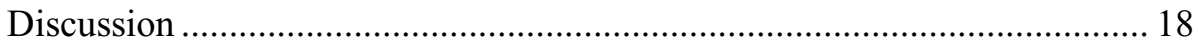

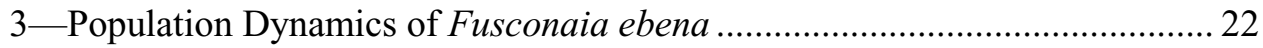

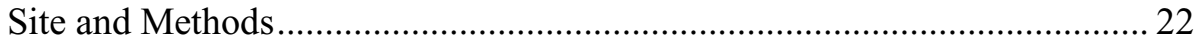

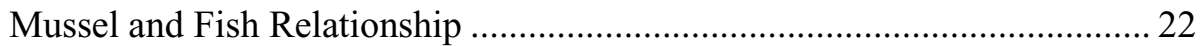

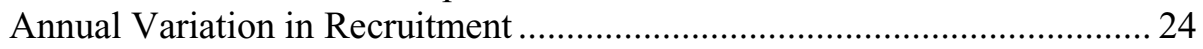

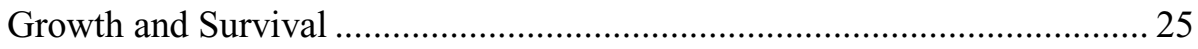

Annual Variation in Hydraulic Conditions ................................................ 26

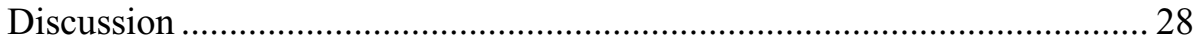

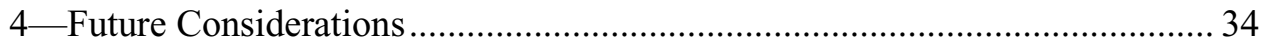

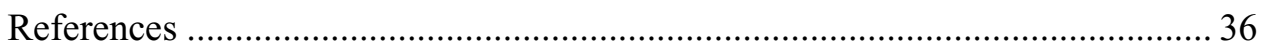

SF 298

\section{List of Figures}

Figure 1. Population size structure, F. ebena, all sites, Olmsted, 29-30 July 1999 7

Figure 2. Distribution of mussel density versus elevation, native mussels at Olmsted, 30 July and 1 August 1999. 8 
Figure 3. Population size structure, C. fluminea, all sites, Olmsted, 2930 July 1999

Figure 4. Population size structure, D. polymorpha, Olmsted, 30 July 1 August 1999.

Figure 5. Fusconaia ebena with less than 6 attached zebra mussels, Olmsted, 1999, semiquantitative sites

Figure 6. Fusconaia ebena with more than 50 attached zebra mussels, Olmsted, 1999, semiquantitative sites.

Figure 7. Light zebra mussel infestation of $F$. ebena, Sites $3 \mathrm{~F}, 5 \mathrm{~N}$, and $5 \mathrm{~F}$

Figure 8. Heavy zebra mussel infestation of $F$. ebena, Sites $8 \mathrm{~N}$ and $8 \mathrm{~F} \ldots \ldots . .14$

Figure 9. Population size structure, F. ebena, Post Creek, 31 July 1999 ........ 16

Figure 10. Population size structure, C. fluminea, Post Creek, 31 July 1999. 18

Figure 11. Population size structure, D. polymorpha, Post Creek, 31 July 1999

Figure 12. Density of F. ebena, lower Ohio River at Olmsted. 24

Figure 13. Demography of the lower Ohio River population of F. ebena ........ 25

Figure 14. Linear regression of $F$. ebena shell length on age.......................... 26

Figure 15. Survivorship curve, $1981 F$. ebena cohort, 1983-1999 ................... 27

Figure 16. Annual discharges of lower Ohio River and upper Mississippi River. 27

Figure 17. Annual lower Ohio River water temperature ................................ 28

Figure 18. Discharge, lower Ohio River, April-July ….................................... 29

Figure 19. 1997 lower Ohio River discharge pattern ..................................... 30

\section{List of Tables}

Table 1. Position of Quantitative Sampling Sites in the Lower Ohio River at Olmsted, 29 and 30 July 1999 ..............................................

Table 2. Site Positions for Semiquantitative Unionid and Quantitative Zebra Mussel Samples in the Lower Ohio River at Olmsted, 30 July and 1 August 1999. 4 
Table 3. Site Positions for Qualitative Unionid Samples in the Lower Ohio River at Olmsted, 30 July and 1 August 1999.

Table 4. Percent Abundance of Freshwater Mussels Collected Using Quantitative Methods in the Lower Ohio River near Olmsted, Illinois, 1999. 5

Table 5. Percent Occurrence of Freshwater Mussels Collected Using Quantitative Methods in the Lower Ohio River near Olmsted, Illinois, 1999

Table 6. Native Mussel and Zebra Mussel Counts per Quadrat at Sites Sampled Semiquantitatively in the Lower Ohio River at Olmsted, 30 July and 1 August 1999 8

Table 7. Relative Abundance of Native Unionids Collected at Olmsted Using Semiquantitative Methods, 1999. 9

Table 8. Relative Abundance of Freshwater Mussels Obtained by Qualitative Methods at Olmsted, 1999

Table 9. Percent Abundance of Freshwater Mussels Collected Using Quantitative Methods in the Lower Ohio River near Post Creek, 1999

Table 10. Percent Occurrence of Freshwater Mussels Collected Using Quantitative Methods in the Lower Ohio River near Post Creek, 1999

Table 11. Percent Abundance and Occurrence of Mussels Collected by Qualitative Methods at Post Creek, 1999.

Table 12. Summary of Demographically Complete Quantitative Samples of Fusconaia ebena from the Lower Ohio River Mussel Bed 


\section{Preface}

The study herein was conducted by the Environmental Laboratory (EL), U.S. Army Engineer Research and Development Center (ERDC), in 1999 for the U.S. Army Engineer District, Louisville, Louisville, KY. The purpose was to analyze spatial distribution, density, recruitment, and community composition of mussels in prominent beds in the lower Ohio River in relation to construction and operation of the Olmsted Locks and Dam Project.

Divers for this study included Messrs. Larry Neill, Robert James, Dennis Baxter, and Steve Fraley, Tennessee Valley Authority. Assistance in the field was provided by Messrs. William B. Green, University of Southern Mississippi, Hattiesburg, and Mark Farr, University of Georgia, Athens. Dr. Andrew C. Miller, Aquatic Ecology and Invasive Species Branch, Ecosystem Evaluation and Engineering Division, EL, was the diving inspector for this work. Assistance in the laboratory was provided by Ms. Katheryn Barko, University of Wisconsin at Stevens Point.

During the conduct of this study Dr. John W. Keeley was Acting Director, EL; Dr. David J. Tazik was Chief, Ecosystem Evaluation and Engineering Division; and Dr. Alfred F. Cofrancesco was Chief, Aquatic Ecology and Invasive Species Branch. Authors of this report were Dr. Barry S. Payne, Aquatic Ecology and Invasive Species Branch, and Dr. Miller.

At the time of publication of this report, Dr. James R. Houston was Director of ERDC, and Mr. A. J. Roberto, Jr. was Acting Commander.

This report should be cited as follows:

Payne, B. S., and Miller, A. C. (2001). "Status of freshwater mussels in the lower Ohio River in relation to the Olmsted Locks and Dam Project: 1999 studies," ERDC/EL TR-01-12, U.S. Army Engineer Research and Development Center, Vicksburg, MS.

The contents of this report are not to be used for advertising, publication, or promotional purposes. Citation of trade names does not constitute an official endorsement or approval of the use of such commercial products. 


\section{Introduction}

\section{Background}

The U.S. Army Engineer District, Louisville, is replacing Locks and Dams 52 and 53 in the lower Ohio River (lower Ohio River) with a new structure located slightly downstream of Lock and Dam 53 (U.S. Army Engineer District, Louisville, 1991) near Olmsted, IL. The new project, now being constructed, is at River Mile (RM) 964.4, existing Lock and Dam 53 is at RM 962.8, and existing Lock and Dam 52 is at RM 938.9. The structure being built will consist of two 33.5 - by $365.8-\mathrm{m}$ ( 110 - by $1,200-\mathrm{ft})$ locks, a $670.6-\mathrm{m}$ - (2,200-ft-) wide navigable pass controlled by remotely operated hydraulic wickets, and a short section of fixed weir connecting the project to the Kentucky shore. The new locks will be on the right descending bank (RDB) on the Illinois side of the river. During periods of normal and low flow, navigation will pass through the locks. During high flow, vessels will use the navigable pass near the center of the channel.

Once completed, the Olmsted project will increase water levels by a maximum of $3 \mathrm{~m} \mathrm{(10} \mathrm{ft)} \mathrm{in} \mathrm{the} \mathrm{pool} \mathrm{above} \mathrm{the} \mathrm{dam} \mathrm{for} \mathrm{approximately} 42$ percent of the year. This increased stage will occur only during normal and low flow. During high-water periods ( 58 percent of the year), dam sections will be lowered to a horizontal position on the river bottom. Upriver stage will be similar to preproject conditions when these dam sections are down. In addition to upstream changes, the hydraulic regimen immediately downstream of the new structure will be altered, as will navigation traffic patterns. Commercial vessels will have to pass close to the RDB when entering or exiting the lock. During high water, commercial vessels will operate in the thalweg at RM 964.4, as they have always done.

Of special interest are the impacts of potential changes in hydraulics and traffic patterns immediately downriver of the new project on a dense and diverse bed of mussels that begins at approximately RM 966 and extends several miles downstream (Payne, Miller, and Shafer 1994; Payne and Miller 1997). This bed includes the endangered species Plethobasus cooperianus (U.S. Fish and Wildlife Service 1991) and is heavily dominated by a single species, Fusconaia ebena. In addition, the bed and other species in the area have economic, ecological, and cultural value deserving protection. Results of previous studies of this prominent mussel bed are included in Williams (1969); Williams and Schuster (1982); Taylor (1989); Neff, Pearson, and Holdren (1981); Miller, Payne, and Siemsen (1986); Miller and Payne (1988, 1991); Payne and Miller (1989); Payne, Miller, and Shafer (1994); and Payne and Miller (1997). 
River hydraulics determine sedimentation, substratum type, bed stability, and, therefore, where a mussel bed can exist in a large river (Coker et al. 1921). Long-term stability of a mussel bed depends on clay, silt, and sand deposited during seasonal low flows being removed by subsequent high flows without eroding underlying gravel and cobble. Reproduction and recruitment of Fusconaia ebena (Lea) potentially relate to hydraulic conditions in several ways (Payne and Miller 2000). Sperm released by males must be entrained in water currents drawn through the mantle cavities of nearby females. Low water velocity associated with low discharge might enhance fertilization success (Yokely 1972). In contrast, high discharge in spring attracts spawning aggregations of Alosa chrysochloris, the only host fish of $F$. ebena glochidia (Coker et al., 1921; Surber 1913), to swiftly flowing water over gravelly shoals (Wallus, Yeager, and Simon 1990). In turn, depositional conditions probably benefit settlement of juvenile mussels after the 1- to 3-week period typically required for metamorphosis (Coker et al. 1921; Howard 1914). Juvenile F. ebena probably settle at a length of approximately $0.15 \mathrm{~mm}$ (Howard 1914) and are thus susceptible to being swept downstream during high discharge.

Planning and construction of the Olmsted Locks and Dam Project have been the cause of regular quantitative sampling of a prominent mussel bed in a mainstream shoal since 1983. Fusconaia ebena heavily dominates the lower Ohio River mussel community (Miller, Payne, and Siemsen 1986); relative abundance of the dominant species typically varies from 70 to 90 percent. The dominant population is characterized by extreme annual variation in recruitment success; approximately a decade ago Payne and Miller (1989) described growth and survival of a cohort of 1981 recruits that dominated the population during the 1980's. Continued monitoring has yielded additional information on growth and survival of that important cohort, the early growth and survival of an even more abundant and recent cohort of 1990 recruits (Payne and Miller 2000), and a much longer record of annual variation in recruitment.

\section{Purpose and Scope}

The objective of the present study is to evaluate the spatial distribution of mussels in the bed downstream of the Olmsted project as well as selected locations in the upriver pool. In addition, this report characterizes recruitment patterns, community composition, and density of nonindigenous species, including the Asian clam, Corbicula fluminea, and the zebra mussel, Dreissena polymorpha. Special emphasis is given to an evaluation of annual variation in recruitment of the dominant unionid, F. ebena, in relation to river hydraulic conditions. These quantitative data can be used to assess environmental effects of alterations of hydraulic regimen, commercial navigation traffic patterns, and benthic scour and deposition associated with construction and operation of the Olmsted project. It is anticipated that studies will continue until the project has operated for at least several years. 


\section{Studies}

\section{Sites and Methods}

Sampling was conducted on 29 July - 1 August 1999 at a major mussel bed downriver of the Olmsted Locks and Dam Project between RM 967 and 969 and at another bed upriver of the project near Post Creek (between RM 956.5 and 957.6). At the Olmsted bed six sites were quantitatively sampled 10 times each using $0.25-\mathrm{m}^{2}$ quadrats (Table 1). Sites 1-3 were spaced within a 50-m (164-ft) radius at approximately RM 967.9. Sites 4-6 were spaced within a 50-m (164-ft) radius at approximately RM 967.6. All six sites were within the elevation range 272 to $274 .{ }^{1}$ The mussel bed spans from $81 \mathrm{~m}(266 \mathrm{ft})$ farshore to $85 \mathrm{~m}(280 \mathrm{ft})$ nearshore (Payne and Miller 1998). Thus, all sites were within the central portion of the bed with respect to depth.

\begin{tabular}{|c|c|c|c|c|}
\hline \multicolumn{5}{|c|}{$\begin{array}{l}\text { Table } 1 \\
\text { Position of Quantitative Sampling Sites in the Lower Ohio River at } \\
\text { Olmsted, } 29 \text { and } 30 \text { July } 1999\end{array}$} \\
\hline Site & Latitude & Longitude & $\begin{array}{l}\text { Depth } \\
\text { m (ft) } \\
\end{array}$ & Elevation, $\mathrm{ft}$ \\
\hline 1 & 3708.550 & 8905.818 & $6.25(20.5)$ & 272 \\
\hline 2 & 3708.533 & 8905.812 & $5.86(19.2)$ & 273 \\
\hline 3 & 3708.535 & 8905.834 & $6.34(20.8)$ & 272 \\
\hline 4 & 3708.812 & 8905.752 & $6.04(19.8)$ & 271 \\
\hline 5 & 3708.811 & 8905.782 & $5.79(19.0)$ & 272 \\
\hline 6 & 3708.784 & 8905.760 & $5.76(18.9)$ & 272 \\
\hline
\end{tabular}

In addition, eight sites were sampled semiquantitatively for unionids and quantatitively for zebra mussels (Table 2). These sites ranged in location from RM 966.9 to 968.3 and el 266 to 281 . As in other years, semiquantitative sites were selected to occur within the central portion of the mussel bed as well as at elevations likely to be near or slightly beyond the nearshore and farshore limits of the bed. Sites 1, 2, and 3 were relatively close to RM 968.2 to 968.3. Sites 4, 5, and 6 were similarly closely spaced from RM 967.9 to 968.0 . Sites 7 and 8

\footnotetext{
${ }^{1}$ All elevations (el) cited herein are in feet referred to mean sea level (msl). To convert to meters, multiply by 0.3048 .
} 
occurred at RM 966.9 and 967.2. Depths and elevations in Table 2 correspond to the position of the dive boat. At each site, one diver moved approximately $30 \mathrm{~m}$ $(100 \mathrm{ft})$ nearshore and a second diver moved approximately $30 \mathrm{~m}(100 \mathrm{ft})$ farshore, describing substratum and mussel density. At their final position, each diver removed all unionids (by feel) from substratum within four placements of a $0.25-\mathrm{m}^{2}$ quadrat. In addition, each diver obtained two samples of substratum using a $0.0625-\mathrm{m}^{2}$ quadrat for determinations of zebra mussel density. However, quantitative samples of zebra mussels were not obtained at Sites 7 and 8.

\begin{tabular}{|c|c|c|c|c|c|c|}
\hline \multicolumn{7}{|c|}{$\begin{array}{l}\text { Table } 2 \\
\text { Site Positions for Semiquantitative Unionid and Quantitative Zebra Mussel Samples in } \\
\text { the Lower Ohio River at Olmsted, } 30 \text { July and } 1 \text { August } 1999\end{array}$} \\
\hline Site & Latitude & Longitude & $\begin{array}{l}\text { Depth } \\
\text { m (ft) }\end{array}$ & Elevation & $\begin{array}{l}\text { Unionid Samples } \\
\text { (n) }\end{array}$ & $\begin{array}{l}\text { Zebra Mussel } \\
\text { Samples (n) }\end{array}$ \\
\hline 1 & 373708.243 & 8906.080 & $\begin{array}{l}3.96(13.0) \\
4.88(16.0) \\
\end{array}$ & $\begin{array}{l}279 \\
276 \\
\end{array}$ & $\begin{array}{l}\text { Nearshore (4) } \\
\text { Farshore (4) }\end{array}$ & $\begin{array}{l}\text { Nearshore (2) } \\
\text { Farshore (2) }\end{array}$ \\
\hline 2 & 3708.267 & 8906.107 & $\begin{array}{l}3.35(11.0) \\
3.66(12.0)\end{array}$ & $\begin{array}{l}281 \\
280\end{array}$ & $\begin{array}{l}\text { Nearshore (4) } \\
\text { Farshore (4) }\end{array}$ & $\begin{array}{l}\text { Nearshore (2) } \\
\text { Farshore (2) }\end{array}$ \\
\hline 3 & 3708.213 & 8905.938 & $\begin{array}{l}6.40(21.0) \\
7.01(23.0)\end{array}$ & $\begin{array}{l}271 \\
269\end{array}$ & $\begin{array}{l}\text { Nearshore (4) } \\
\text { Farshore (4) }\end{array}$ & $\begin{array}{l}\text { Nearshore (2) } \\
\text { Farshore (2) }\end{array}$ \\
\hline 4 & 3708.509 & 8905.926 & $\begin{array}{l}3.96(13.0) \\
4.88(16.0)\end{array}$ & $\begin{array}{l}279 \\
276\end{array}$ & $\begin{array}{l}\text { Nearshore (4) } \\
\text { Farshore (4) }\end{array}$ & $\begin{array}{l}\text { Nearshore (2) } \\
\text { Farshore (2) }\end{array}$ \\
\hline 5 & 3708.482 & 8905.874 & $\begin{array}{l}6.09(20.0) \\
6.40(21.0)\end{array}$ & $\begin{array}{l}272 \\
271\end{array}$ & $\begin{array}{l}\text { Nearshore (4) } \\
\text { Farshore (4) }\end{array}$ & $\begin{array}{l}\text { Nearshore (2) } \\
\text { Farshore (2) }\end{array}$ \\
\hline 6 & 3708.431 & 8905.793 & $\begin{array}{l}7.62(25.0) \\
7.92(26.0)\end{array}$ & $\begin{array}{l}267 \\
266\end{array}$ & $\begin{array}{l}\text { Nearshore (4) } \\
\text { Farshore (4) }\end{array}$ & $\begin{array}{l}\text { Nearshore (2) } \\
\text { Farshore (2) }\end{array}$ \\
\hline 7 & 3709.375 & 8905.595 & $\begin{array}{l}6.09(20.0) \\
6.40(21.0)\end{array}$ & $\begin{array}{l}272 \\
271\end{array}$ & $\begin{array}{l}\text { Nearshore (4) } \\
\text { Farshore (4) }\end{array}$ & $\begin{array}{l}\text { Nearshore (0) } \\
\text { Farshore (0) }\end{array}$ \\
\hline 8 & 3709.108 & 8905.707 & $\begin{array}{l}5.49(18.0) \\
6.09(20.0)\end{array}$ & $\begin{array}{l}274 \\
272 \\
\end{array}$ & $\begin{array}{l}\text { Nearshore (4) } \\
\text { Farshore (4) }\end{array}$ & $\begin{array}{l}\text { Nearshore (0) } \\
\text { Farshore }(0)\end{array}$ \\
\hline
\end{tabular}

Lastly, a single set of qualitative samples was collected for native mussels, followed by a 30-min selective search by each of two divers to collect all "nonF. ebena." The locations of these searches are indicated in Table 3. Both efforts enhanced community composition data. Because $F$. ebena heavily dominates the Olmsted bed, collections of mussels that specifically exclude this species enhance the likelihood of obtaining locally rare species, including $P$. cooperianus.

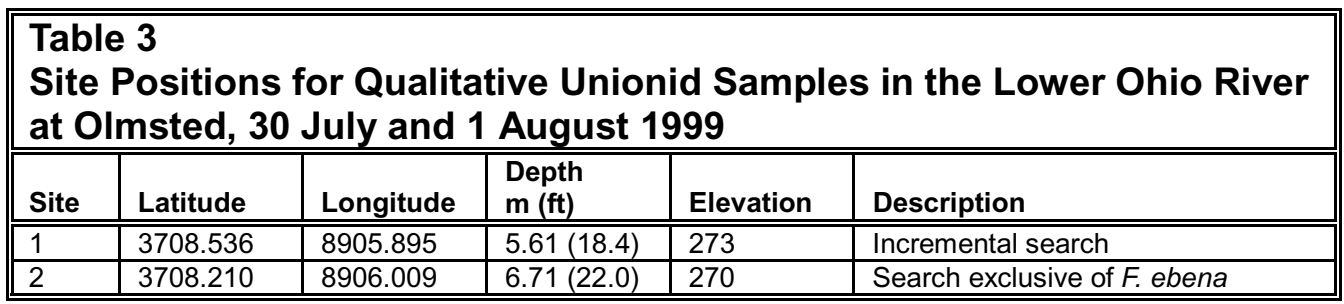

At the Post Creek bed two sites were quantitatively sampled for native unionids by removing substratum with mussels from replicate $(n=10) 0.25-\mathrm{m}^{2}$ quadrats. A nearshore site (3.9-m (13-ft) depth) was sampled at $3113.801 \mathrm{~N}$ $8857.290 \mathrm{~W}$. A farshore site (4.9-m (16-ft) depth) was sampled at $3713.765 \mathrm{~N}$, 8857.243 W. At both locations, 10 substratum samples were removed from $0.0625-\mathrm{m}^{2}$ quadrats for determinations of zebra mussel density. Also at the farshore location, a set of qualitative samples of native unionids was collected to 
more fully evaluate community composition. Qualitative sampling consisted of divers collecting, first in three sets of 5 mussels each and then in nine sets of 20 mussels each, all individuals encountered by touch.

\section{Results}

\section{Olmsted}

Quantitative studies. Five of six sites quantitatively sampled at Olmsted in 1999 were heavily dominated by $F$. ebena (Tables 4 and 5). Only at site 4, where only four mussels were collected from a total of ten $0.25-\mathrm{m}^{2}$ quadrats, was $F$. ebena not heavily dominant. The combined results of quantitative sampling indicated $F$. ebena's overwhelming dominance. Fusconaia ebena composed 95.8 percent of the mussel community sampled by quantitative methods at Olmsted.

\begin{tabular}{|c|c|c|c|c|c|c|c|}
\hline \multirow{3}{*}{$\begin{array}{l}\text { Table } 4 \\
\text { Percent Abundance } \\
\text { Lower Ohio River Ne } \\
\\
\text { Species }\end{array}$} & $\begin{array}{l}\text { of Fres } \\
\text { ear Olm }\end{array}$ & $\begin{array}{l}\text { Iater M } \\
\text { a, Illin }\end{array}$ & $\begin{array}{l}\text { els Col } \\
1999\end{array}$ & ed Us & Quantit & e Met & s in the \\
\hline & \multicolumn{6}{|c|}{ Subsite Number } & \multirow[b]{2}{*}{ Total } \\
\hline & 1 & 2 & 3 & 4 & 5 & 6 & \\
\hline Fusconaia ebena & 95.80 & 91.10 & 94.77 & 25.00 & 98.88 & 97.81 & 95.77 \\
\hline Quadrula metanevra & 0.84 & 6.85 & 1.96 & 25.00 & 0.00 & 0.00 & 1.71 \\
\hline $\begin{array}{l}\text { Quadrula pustulosa } \\
\text { pustulosa }\end{array}$ & 0.00 & 0.00 & 0.00 & 0.00 & 0.56 & 1.09 & 0.46 \\
\hline Quadrula nodulata & 0.00 & 0.68 & 0.00 & 0.00 & 0.56 & 0.37 & 0.34 \\
\hline Ellipsaria lineolata & 0.84 & 0.00 & 0.65 & 0.00 & 0.00 & 0.37 & 0.34 \\
\hline Obliquaria reflexa & 0.84 & 0.00 & 0.65 & 0.00 & 0.00 & 0.37 & 0.34 \\
\hline Elliptio crassidens & 0.00 & 0.68 & 0.65 & 0.00 & 0.00 & 0.00 & 0.23 \\
\hline Amblema plicata plicata & 0.00 & 0.00 & 1.31 & 0.00 & 0.00 & 0.00 & 0.23 \\
\hline Ligumia recta & 0.84 & 0.00 & 0.00 & 25.00 & 0.00 & 0.00 & 0.23 \\
\hline Pleurobema cordatum & 0.84 & 0.00 & 0.00 & 0.00 & 0.00 & 0.00 & 0.11 \\
\hline Leptodea fragilis & 0.00 & 0.00 & 0.00 & 25.00 & 0.00 & 0.00 & 0.11 \\
\hline Obovaria olivaria & 0.00 & 0.68 & 0.00 & 0.00 & 0.00 & 0.00 & 0.11 \\
\hline Total individuals & 119 & 146 & 153 & 4 & 179 & 274 & 875 \\
\hline Total species & 6 & 5 & 6 & 4 & 3 & 5 & 12 \\
\hline$\%$ Species $<30 \mathrm{~mm}$ & & & & & & & 41.67 \\
\hline$\%$ Individuals $<30 \mathrm{~mm}$ & & & & & & & 2.97 \\
\hline Menhinick's index & & & & & & & 0.41 \\
\hline Shannon's diversity index & & & & & & & 0.26 \\
\hline Evenness & & & & & & & 0.3 \\
\hline
\end{tabular}




\begin{tabular}{|c|c|c|c|c|c|c|c|}
\hline \multicolumn{8}{|c|}{$\begin{array}{l}\text { Table } 5 \\
\text { Percent Occurrence of Freshwater Mussels Collected Using Quantitative Methods in the } \\
\text { Lower Ohio River Near Olmsted, Illinois, } 1999\end{array}$} \\
\hline \multirow[b]{2}{*}{ Species } & \multicolumn{6}{|c|}{ Subsite Number } & \multirow[b]{2}{*}{ Total } \\
\hline & 1 & 2 & 3 & 4 & 5 & 6 & \\
\hline F. ebena & 100 & 100 & 100 & 10 & 100 & 100 & 85.00 \\
\hline Q. metanevra & 10 & 60 & 20 & 10 & 0 & 0 & 16.67 \\
\hline Q.p.pustulosa & 0 & 0 & 0 & 0 & 10 & 30 & 6.67 \\
\hline Q. nodulata & 0 & 10 & 0 & 0 & 10 & 10 & 5.00 \\
\hline E. lineolata & 10 & 0 & 10 & 0 & 0 & 10 & 5.00 \\
\hline O. reflexa & 10 & 0 & 10 & 0 & 0 & 10 & 5.00 \\
\hline E. crassidens & 0 & 10 & 10 & 0 & 0 & 0 & 3.33 \\
\hline A.p.plicata & 0 & 0 & 20 & 0 & 0 & 0 & 3.33 \\
\hline L. recta & 10 & 0 & 0 & 10 & 0 & 0 & 3.33 \\
\hline P. cordatum & 10 & 0 & 0 & 0 & 0 & 0 & 1.67 \\
\hline L. fragilis & 0 & 0 & 0 & 10 & 0 & 0 & 1.67 \\
\hline O. olivaria & 0 & 10 & 0 & 0 & 0 & 0 & 1.67 \\
\hline Total samples & 10 & 10 & 10 & 10 & 10 & 10 & 60 \\
\hline
\end{tabular}

Recently recruited mussels (individuals less than $30 \mathrm{~mm}$ long) composed only 3.0 percent of the community; however, nearly half of all species collected were represented by at least one such recent recruit. This community-wide evidence of recent recruitment was especially impressive because a total of only 28 individuals of species other than F. ebena were obtained in quantitative samples.

Due to the heavy dominance of $F$. ebena, diversity was extremely low, measuring just 0.26 (Shannon's Index) and 0.41 (Menhinick's index). A total of 12 species were included among the 875 individuals collected. Evenness expresses Shannon's index as a fraction of maximum possible diversity, which corresponds to equal abundance of all species (Pileou 1969). In the case of 12 species, maximum diversity equals 2.48 (i.e., the natural logarithm of 12). Thus, eveness was only 0.10 . By any measure, the community at Olmsted, although rich in species, is low in diversity due to the extreme dominance of $F$. ebena.

Sites 1,2 , and 3 were within a 50-m (164-ft) radius at approximately RM 967.85 and within elevations ranging only from 272 to 274 . The nearshore and farshore edges of the bed tended to occur at approximately the 279 and 267 elevation contours. Mussel density among these sites was similar; average density ranged only from 47.6 to 61.2 individuals per $\mathrm{m}^{2}$ at Sites 1 and 3, respectively. Divers described substratum at all three sites as $0.15-0.2 \mathrm{~m}(6-8 \mathrm{in}$.) of sand overlaying gravel.

Sites 4,5 , and 6 were within a 100-m (328-ft) radius at approximately RM 967.6 and within an elevation range of 273 to 274 . Average density of 
mussels was only 1.5 individuals per $\mathrm{m}^{2}$ at Site 4 . In contrast, density at Sites 5 and 6 averaged 71.6 and 109.6 individuals per $\mathrm{m}^{2}$, respectively. This inconsistency demonstrates a high degree of patchiness within a small area of the mussel bed. Divers described substratum at all three sites as $0.15-0.2 \mathrm{~m}(6-8 \mathrm{in}$.) of sand overlaying gravel.

Fusconaia ebena was the only native unionid obtained in sufficient numbers for detailed inspection of population size structure (Figure 1). Fusconaia ebena at Olmsted in 1999 ranged from 8 to $86 \mathrm{~mm}$ long. However, greater than 90 percent of the population consisted of individuals ranging only from 46 to $70 \mathrm{~mm}$. This dominant size class represented a cohort of 1990 recruits that was first apparent in the population in 1991 and not fully represented in quantitative samples until 1992 (Payne and Miller 2000). A second noteworthy cohort was centered at approximately 76 to $78 \mathrm{~mm}$. That minor cohort of large mussels represented the remaining survivors of the once-dominant 1981 cohort (Payne and Miller 2000). Lastly, a minor but substantial cohort was centered at 16 to $20 \mathrm{~mm}$; these small mussels probably represented 1997 recruitment.

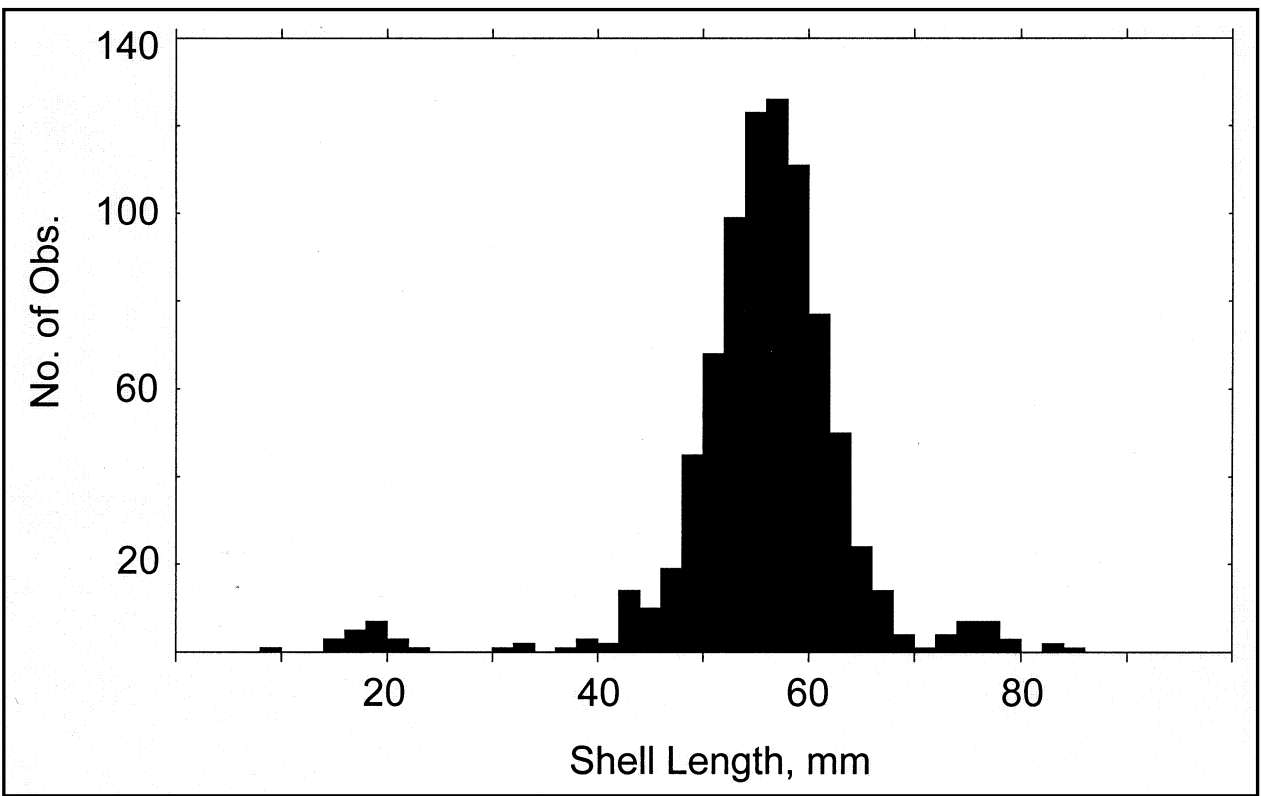

Figure 1. Population size structure, F. ebena, all sites, Olmsted, 29-30 July 1999

Semiquantitative mapping. Figure 2 shows the distribution of mussel density within semiquantitative samples in relation to elevation. Table 6 summarizes density estimates for each site. Sites 1, 2, and 3 were located approximately at RM 968.2 to 968.3 . Elevation of the river bottom at these sites ranged from approximately 269 to 281 . Sites 4,5 , and 6 were located at 


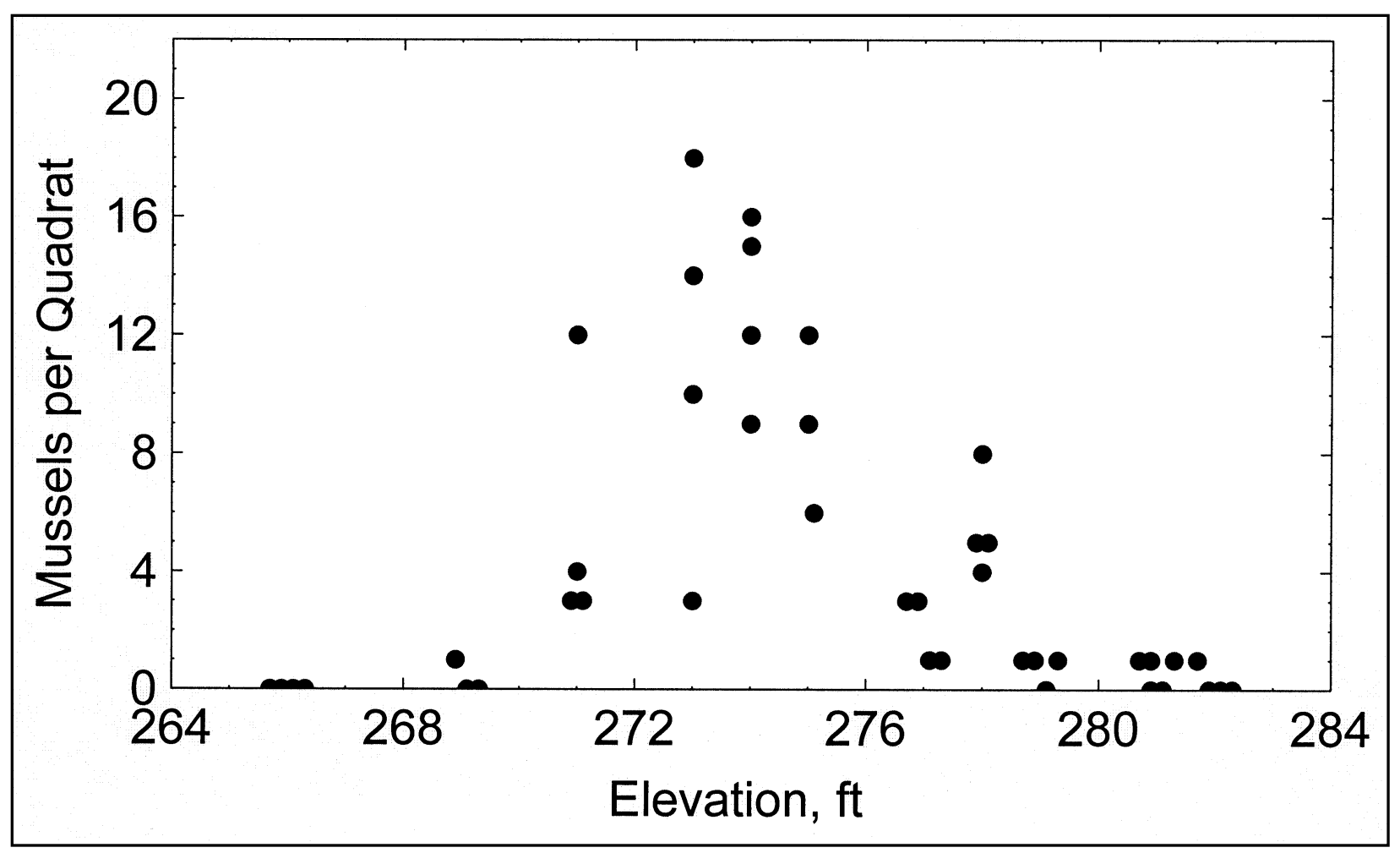

Figure 2. Distribution of mussel density versus elevation, native mussels at Olmsted, 30 July and 1 August 1999

\begin{tabular}{|c|c|c|c|c|c|}
\hline \multicolumn{6}{|c|}{$\begin{array}{l}\text { Table } 6 \\
\text { Native Mussel and Zebra Mussel Counts per Quadrat at Sites Sampled Semi- } \\
\text { Quantitatively in the Lower Ohio River at Olmsted, } 30 \text { July and } 1 \text { August } 1999\end{array}$} \\
\hline Site & Diver Position & $\begin{array}{l}\text { Depth } \\
\mathrm{m}(\mathrm{ft})\end{array}$ & Elevation & $\begin{array}{l}\text { Native Mussels } \\
\text { per } 0.25 \mathrm{~m}^{2} \\
\text { Mean (SD) }\end{array}$ & $\begin{array}{l}\text { Zebra Mussels }{ }^{1} \\
\text { per } 0.0625 \mathrm{~m}^{2}\end{array}$ \\
\hline 1 & $\begin{array}{l}\text { Nearshore } \\
\text { Farshore }\end{array}$ & $\begin{array}{l}3.96(13.0) \\
4.88(16.0)\end{array}$ & $\begin{array}{l}279 \\
276\end{array}$ & $\begin{array}{l}0.75(0.50) \\
5.50(1.73)\end{array}$ & $\begin{array}{l}194,593 \\
524,504\end{array}$ \\
\hline 2 & $\begin{array}{l}\text { Nearshore } \\
\text { Farshore } \\
\end{array}$ & $\begin{array}{l}3.35(11.0) \\
3.66(12.0)\end{array}$ & $\begin{array}{l}281 \\
280\end{array}$ & $\begin{array}{l}0.25(0.50) \\
0.50(0.58)\end{array}$ & $\begin{array}{l}182,380 \\
380,299\end{array}$ \\
\hline 3 & $\begin{array}{l}\text { Nearshore } \\
\text { Farshore }\end{array}$ & $\begin{array}{l}6.40(21.0) \\
7.01(23.0)\end{array}$ & $\begin{array}{l}271 \\
269 \\
\end{array}$ & $\begin{array}{l}13.00(3.16) \\
5.50(4.36)\end{array}$ & $\begin{array}{l}388,392 \\
10,1\end{array}$ \\
\hline 4 & $\begin{array}{l}\text { Nearshore } \\
\text { Farshore }\end{array}$ & $\begin{array}{l}3.96(13.0) \\
4.88(16.0)\end{array}$ & $\begin{array}{l}279 \\
276\end{array}$ & $\begin{array}{l}0.75(0.50) \\
2.00(1.15)\end{array}$ & $\begin{array}{l}200,928 \\
192,115\end{array}$ \\
\hline 5 & $\begin{array}{l}\text { Nearshore } \\
\text { Farshore }\end{array}$ & $\begin{array}{l}6.09(20.0) \\
6.40(21.0)\end{array}$ & $\begin{array}{l}272 \\
271\end{array}$ & $\begin{array}{l}8.25(2.87) \\
11.25(6.40)\end{array}$ & $\begin{array}{l}110,34 \\
460,392\end{array}$ \\
\hline 6 & $\begin{array}{l}\text { Nearshore } \\
\text { Farshore }\end{array}$ & $\begin{array}{l}7.62(25.0) \\
7.92(26.0)\end{array}$ & $\begin{array}{l}267 \\
266\end{array}$ & $\begin{array}{l}0.25(0.50) \\
0.00(0.00)\end{array}$ & $\begin{array}{l}0,0 \\
0,0\end{array}$ \\
\hline 7 & $\begin{array}{l}\text { Nearshore } \\
\text { Farshore }\end{array}$ & $\begin{array}{l}6.09(20.0) \\
6.40(21.0)\end{array}$ & $\begin{array}{l}272 \\
271\end{array}$ & $\begin{array}{l}0.75(0.96) \\
2.00(0.82)\end{array}$ & $\begin{array}{l}\text { Not sampled } \\
\text { Not sampled }\end{array}$ \\
\hline 8 & $\begin{array}{l}\text { Nearshore } \\
\text { Farshore }\end{array}$ & $\begin{array}{l}5.49(18.0) \\
6.09(20.0)\end{array}$ & $\begin{array}{l}274 \\
272\end{array}$ & $\begin{array}{l}9.25(3.30) \\
21.50(3.42)\end{array}$ & $\begin{array}{l}\text { Not sampled } \\
\text { Not sampled }\end{array}$ \\
\hline
\end{tabular}


approximately RM 967.9 to 968.0 and ranged in elevation from 266 to 279 . Sites 7 and 8 were at RM 966.9 and 967.2, respectively, both at an elevation of approximately 271 to 274 . The mussel bed spans from approximately 85 to $81 \mathrm{~m}$ ( 280 to $265 \mathrm{ft}$ ) and areas with high mussel density tend to occur at central elevations within this range (Payne and Miller 1998). Native mussel density in semiquantitative samples ranged from 0 to 22 individuals per $0.25-\mathrm{m}^{2}$ quadrat. Sites 3, 5, and 8 supported the highest density assemblages; all three sites were at central elevations within the bed. Sites 1 and 4 were near the nearshore limit of the bed; low density at these sites indicated their marginal location. Sites 3 and 6 were near the farshore limit of the bed and also supported low-density assemblages of mussels.

Fusconaia ebena heavily dominated semiquantitative samples. Relative abundance of the dominant species equaled 84.4 percent (Table 7). A total of 15 species were represented among 326 mussels collected by semiquantitative sampling. Species obtained by semiquantitative but not quantitative methods were Quadrula quadrula, Lampsilis teres, Megalonaias nervosa, Cyclonaias tuberculata, and Potamilus alatus. Except for Q. quadrula, these species were represented by only one or two individuals. Thus, the difference between quantitative and semiquantitative methods reflected mainly inconsistency in obtaining locally rare species with a moderate sampling effort.

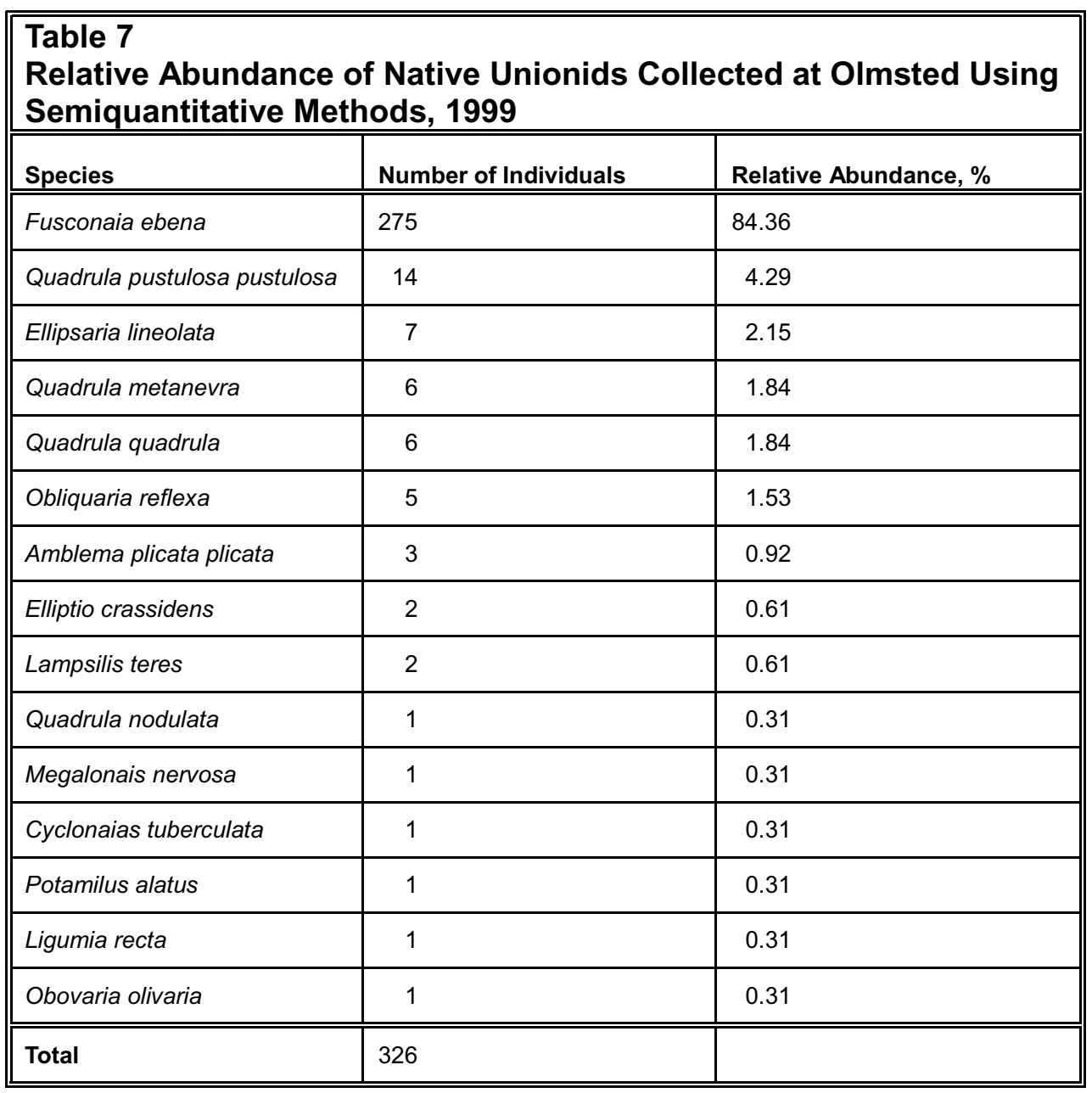


The results of semiquantitative mapping were the same as for quantitative studies.

Qualitative studies. A total of 11 species of native mussels were represented among 202 individuals collected qualitatively at Olmsted (Table 8). Although $F$. ebena heavily dominated ( 72 percent), dominance was less than indicated by more objective quantitative or semiquantitative methods. Ellipsaria lineolata, Quadrula metanevra, and Quadrula pustulosa pustulosa were moderately abundant, composing 9.9, 7.4, and 5.9 percent, respectively, of the qualitative sample of the unionid community.

\begin{tabular}{|c|c|c|}
\hline \multicolumn{3}{|c|}{$\begin{array}{l}\text { Table } 8 \\
\text { Relative Abundance of Mussels Obtained by Qualitative Methods at } \\
\text { Olmsted, } 1999\end{array}$} \\
\hline Species & $\%$ Abundance & $\%$ Occurrence \\
\hline Fusconaia ebena & 71.78 & 91.67 \\
\hline Ellipsaria lineolata & 9.90 & 83.33 \\
\hline Quadrula metanevra & 7.43 & 58.33 \\
\hline Quadrula pustulosa pustulosa & 5.94 & 75.00 \\
\hline Obovaria olivaria & 0.99 & 16.67 \\
\hline Amblema plicata plicata & 0.99 & 16.67 \\
\hline Elliptio dilatata & 0.99 & 16.67 \\
\hline Ligumia recta & 0.50 & 8.33 \\
\hline Quadrula quadrula & 0.50 & 8.33 \\
\hline Elliptio crassidens & 0.50 & 8.33 \\
\hline Megalonais nervosa & 0.50 & 8.33 \\
\hline Total individuals & 202 & \\
\hline Total species & 11 & \\
\hline
\end{tabular}

A selective qualitative search for mussels exclusive of $F$. ebena led to collection of 25 individuals and 8 species. Quadrula metanevra and Q. $p$. pustulosa were the most abundant species. A single specimen of the endangered species, $P$. cooperianus, was included in this sample. Three small $F$. ebena were obtained. Small mussels were difficult for divers to positively identify to species by touch alone; however, the diligence of the search made by divers was indicated by the retrieval of such small individuals.

Cumulative species richness. The best estimate of richness was provided by combining all samples, whether quantitative, semiquantitative, qualitative, or selectively qualitative. A total of 19 species were represented among 1,428 mussels collected at Olmsted in 1999. The total richness of this mussel bed was 
estimated at 30 in 1992 based on a cumulative sample of nearly 10,000 individuals (Payne, Miller, and Shafer 1994). Species collected recently from the bed but not in 1999 include Actinonaias ligamentina, Anodonta imbecillis, Arcidens confragosus, F. flava, L. ovata, Lasmigona complanata, P. cyphyus, $P$. purpuratus, Tritogonia verrucosa, Truncilla truncata, and T. donaciformis. With the exception of $T$. truncata and $T$. donaciformis, which commonly composed 5-20 percent of the community in earlier samples (Payne and Miller 1997, 1998, and 1999; Payne, Miller, and Shafer 1994), all species not obtained in 1999 are locally rare and likely not to be obtained in a moderate-sized sample.

Both $T$. truncata and $T$. donaciformis (as well as A. imbecillis) are characterized by small maximum adult size and short lifespan (approximately 2-4 years). Such species are especially susceptible to decimation by the extremely high density infestation of D. polymorpha in the mid-1990's. Like relatively short-lived pleurocerid snails that were previously dense on the mussel bed, the absence of $T$. truncata and $T$. donaciformis from the mussel bed since the mid-1990s probably reflects local extirpation.

Corbicula fluminea. The $C$. fluminea population at Olmsted was represented by a single cohort of small individuals ranging from 7 to $16 \mathrm{~mm}$ (Figure 3 ). Density of this population at Olmsted was low, ranging from an average of only 0-6 individuals per $\mathrm{m}^{2}$ among the six quantitatively sampled sites. Thus, the sample available for demographic analysis was not large $(n=45)$.

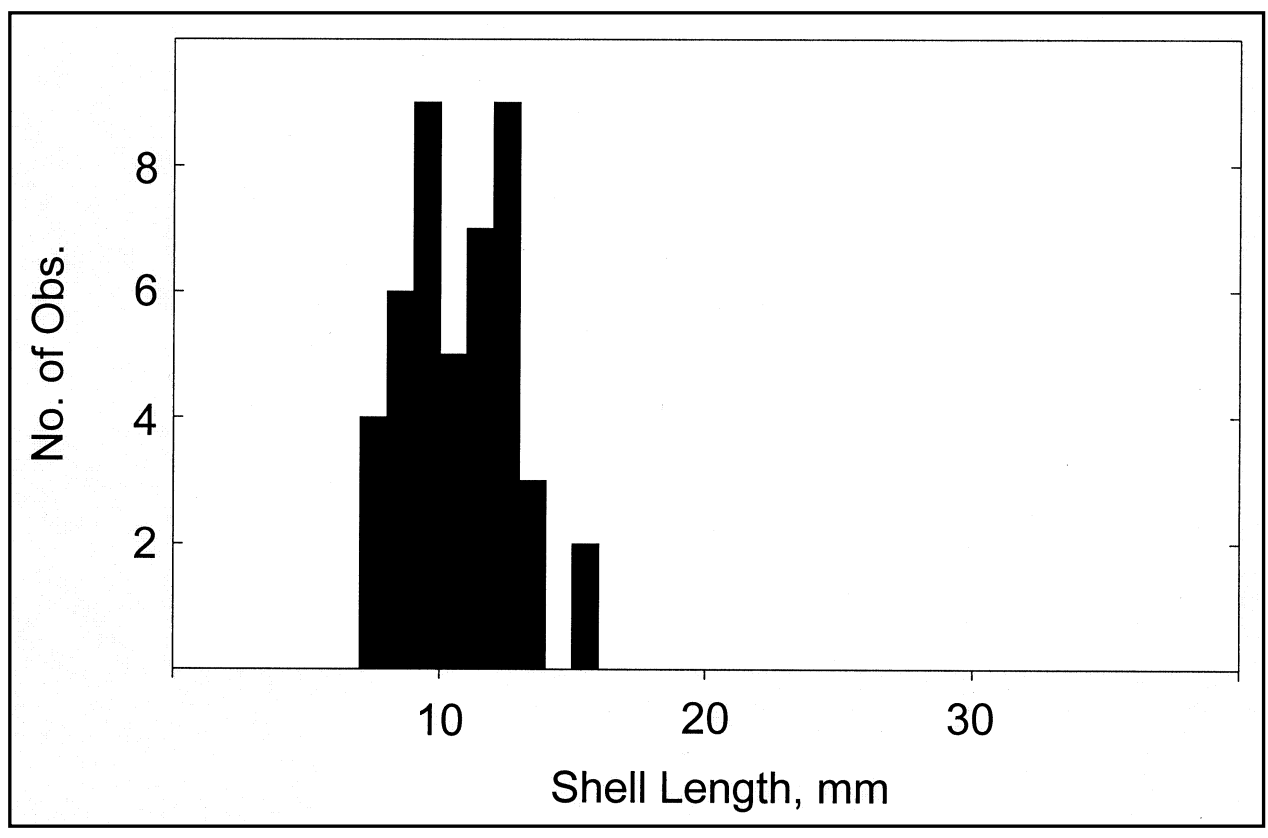

Figure 3. Population size structure, C. fluminea, all sites, Olmsted, 29-30 July 1999

Dreissena polymorpha. The density of $D$. polymorpha at Olmsted ranged from 0 to 14,484 individuals per $\mathrm{m}^{2}$ (Table 6). No individuals were obtained in the four samples collected at semiquantitative Site 6; both the nearshore and farshore locations at this site were farshore of the mussel bed in very erosional 
sandy substratum. The farshore location at site 3 was also in coarse, shifting sand that supported a moderately dense assemblage of unionids (12 to 48 individuals per $\mathrm{m}^{2}$ ) but an extremely low density assemblage of $D$. polymorpha (16 to 160 individuals per $\mathrm{m}^{2}$ ). At all other locations, substratum conditions were relatively stable; $D$. polymorpha density averaged 5,405 individuals per $\mathrm{m}^{2}$ among such sites.

The population of D. polymorpha at both Olmsted sites comprised three cohorts (Figure 4). The dominant cohort was one of small individuals (mostly 4 to $10 \mathrm{~mm}$ long) that probably repesented 1999 recruitment. A much less abundant but still clear cohort of intermediate-sized individuals (mostly 12 to $18 \mathrm{~mm}$ ) probably represented 1998 recruitment. An even less abundant cohort of large mussels (21 to $29 \mathrm{~mm}$ ) probably represented 1997 recruitment. Thus, abundance by year class diminished with age - a pattern consistent with a relatively stable population.

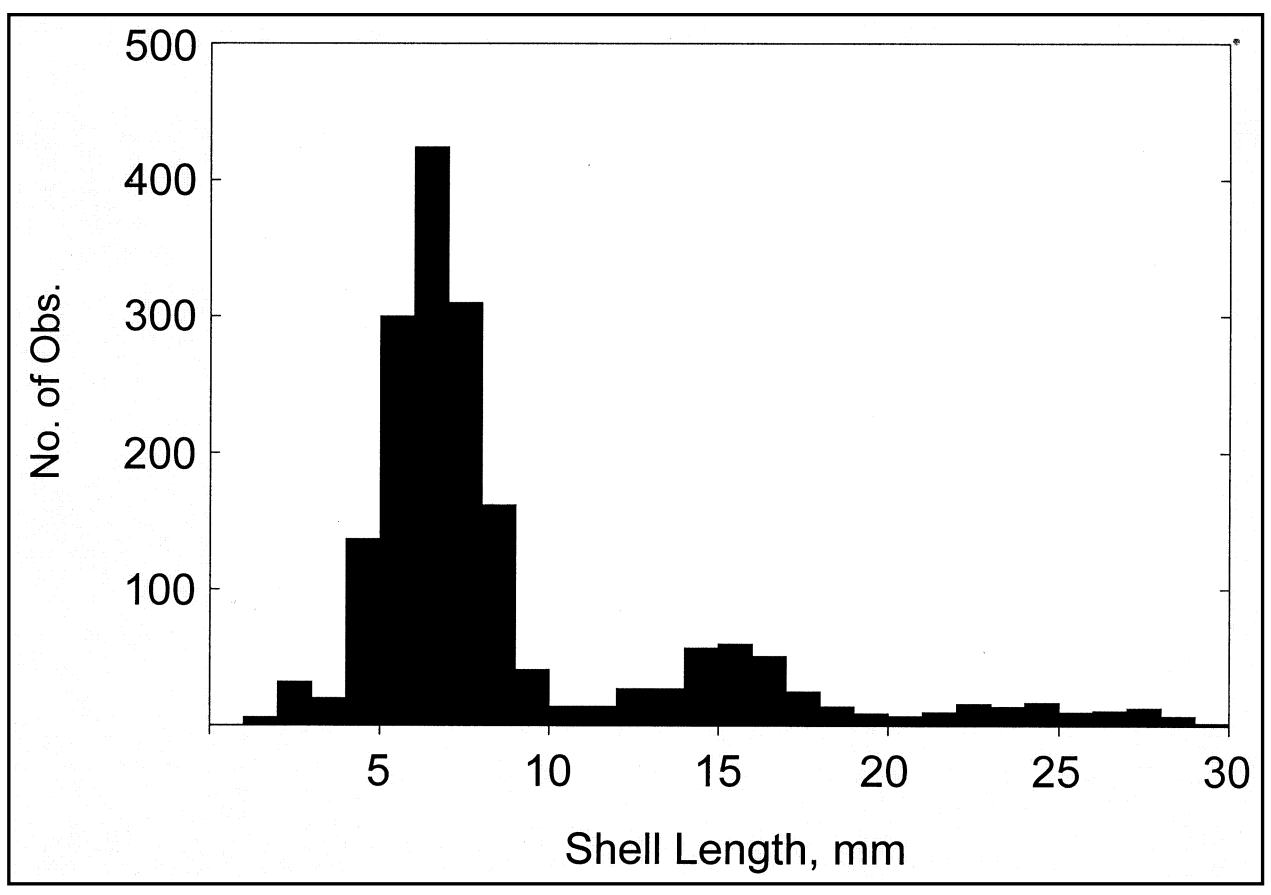

Figure 4. Population size structure, D. polymorpha, Olmsted, 30 July 1 August 1999

The degree of infestation of native mussels by D. polymorpha varied among the eight sites sampled semiquantitatively. Actual counts of live zebra mussels attached to unionids were made if only 0-9 D. polymorpha were attached. Categories of 10-50 and $>50$ attached zebra mussels were used to describe moderately and heavily infested unionids. The frequency of $F$. ebena with light (0-5) and heavy ( $>50)$ infestations of $D$. polymorpha are shown, by site, in Figures 5 and 6. Most lightly infested unionids were collected in Sites 3 and 5, although the nearshore location at Site 3 also included a reasonably high number of heavily infested unionids. Most heavily infested unionids were from Site 8 . 


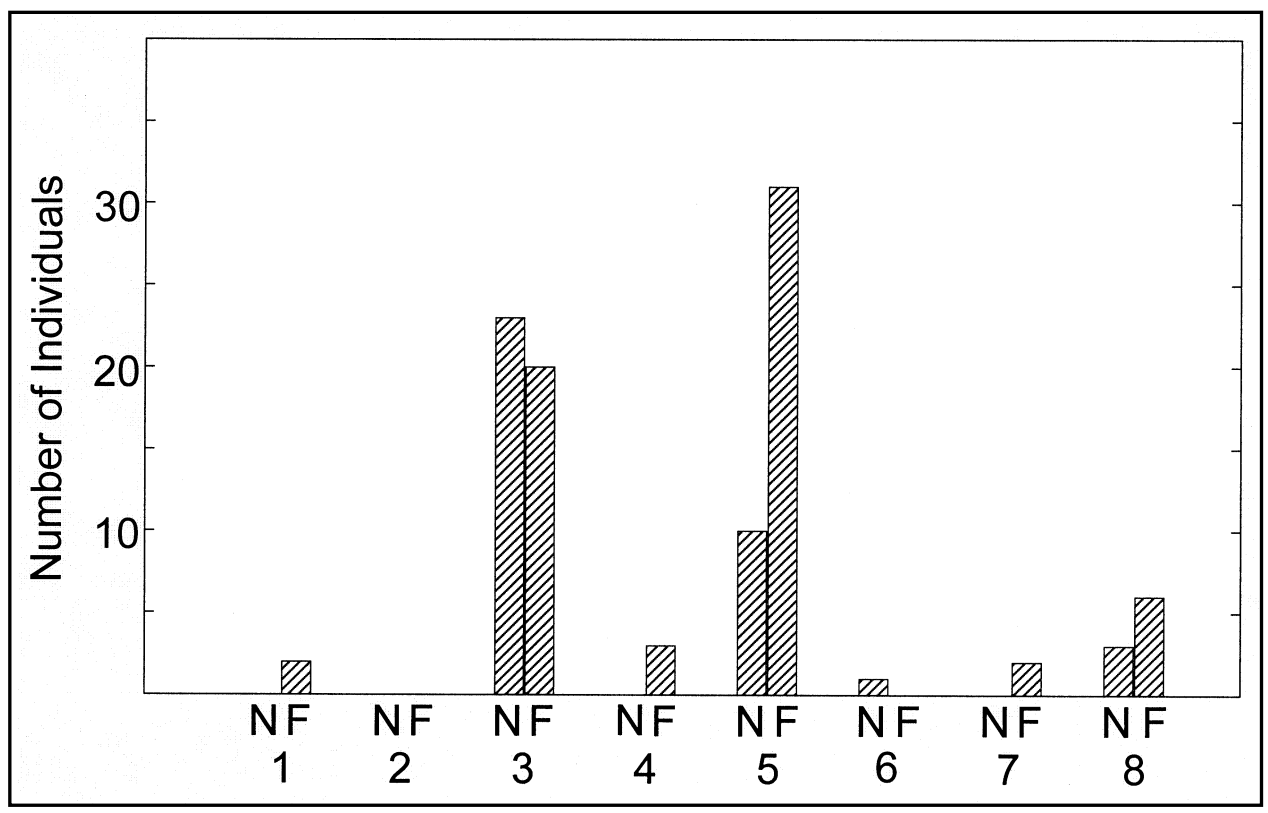

Figure 5. Fusconaia ebena with less than 6 attached zebra mussels, Olmsted, 1999, semiquantitative sites

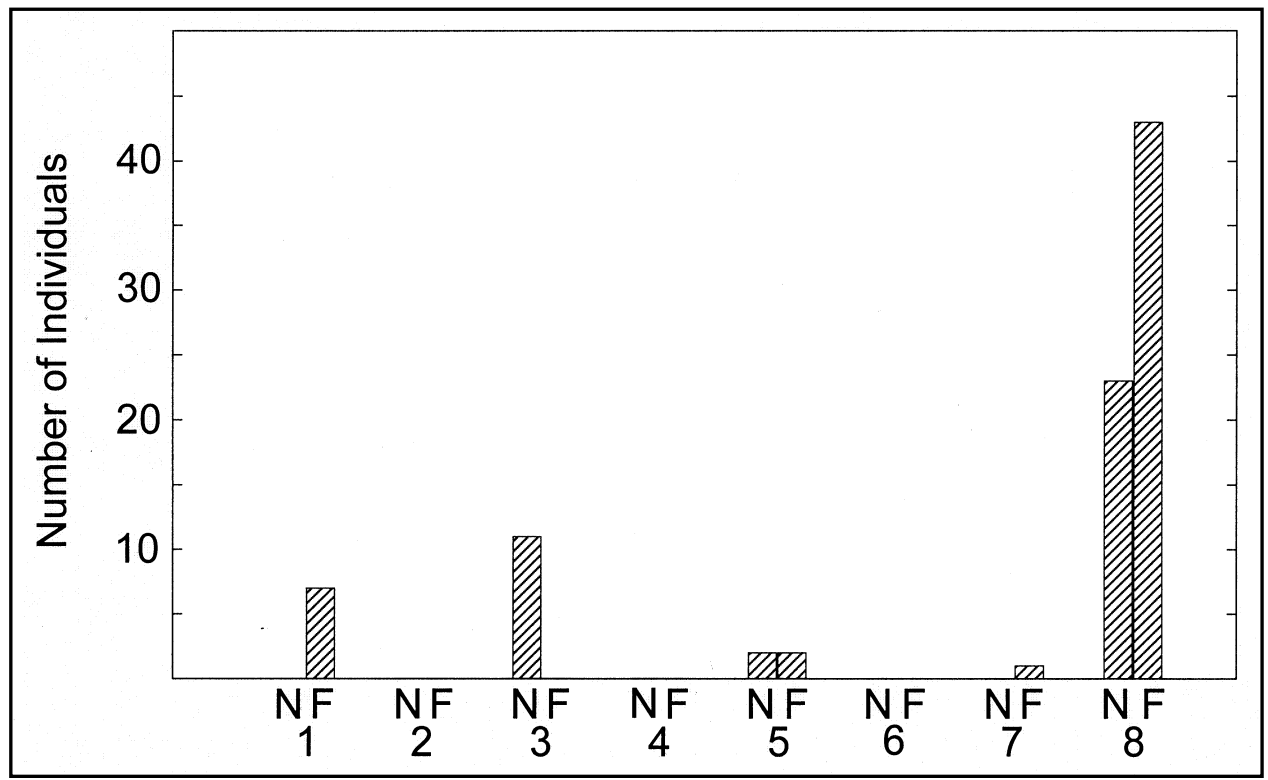

Figure 6. Fusconaia ebena with more than 50 attached zebra mussels, Olmsted, 1999, semiquantitative sites

The size structure of $F$. ebena differed between sites characterized by light versus heavy infestation of $D$. polymorpha (Figures 7 and 8). At lightly infested Sites 3F, 5N, and 5F the 1990 cohort of $F$. ebena had an average length of $58 \mathrm{~mm}$ and ranged from 44 to $68 \mathrm{~mm}$. In contrast, the $1990 \mathrm{~F}$. ebena cohort at Sites $8 \mathrm{~N}$ and $8 \mathrm{~F}$ (heavily infested) had an average length of $50 \mathrm{~mm}$ and ranged from 42 to $62 \mathrm{~mm}$. 


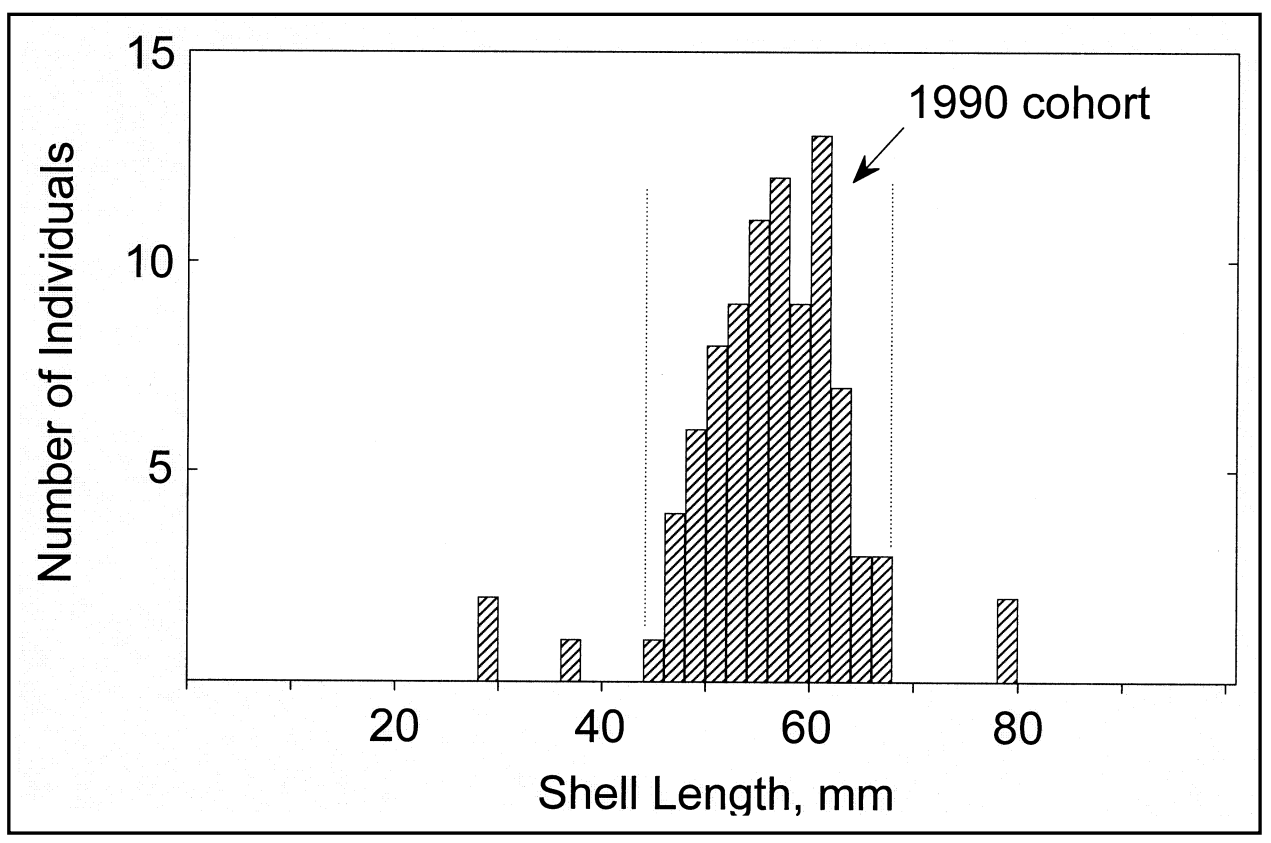

Figure 7. Light zebra mussel infestation of $F$. ebena, Sites $3 \mathrm{~F}, 5 \mathrm{~N}$, and $5 \mathrm{~F}$

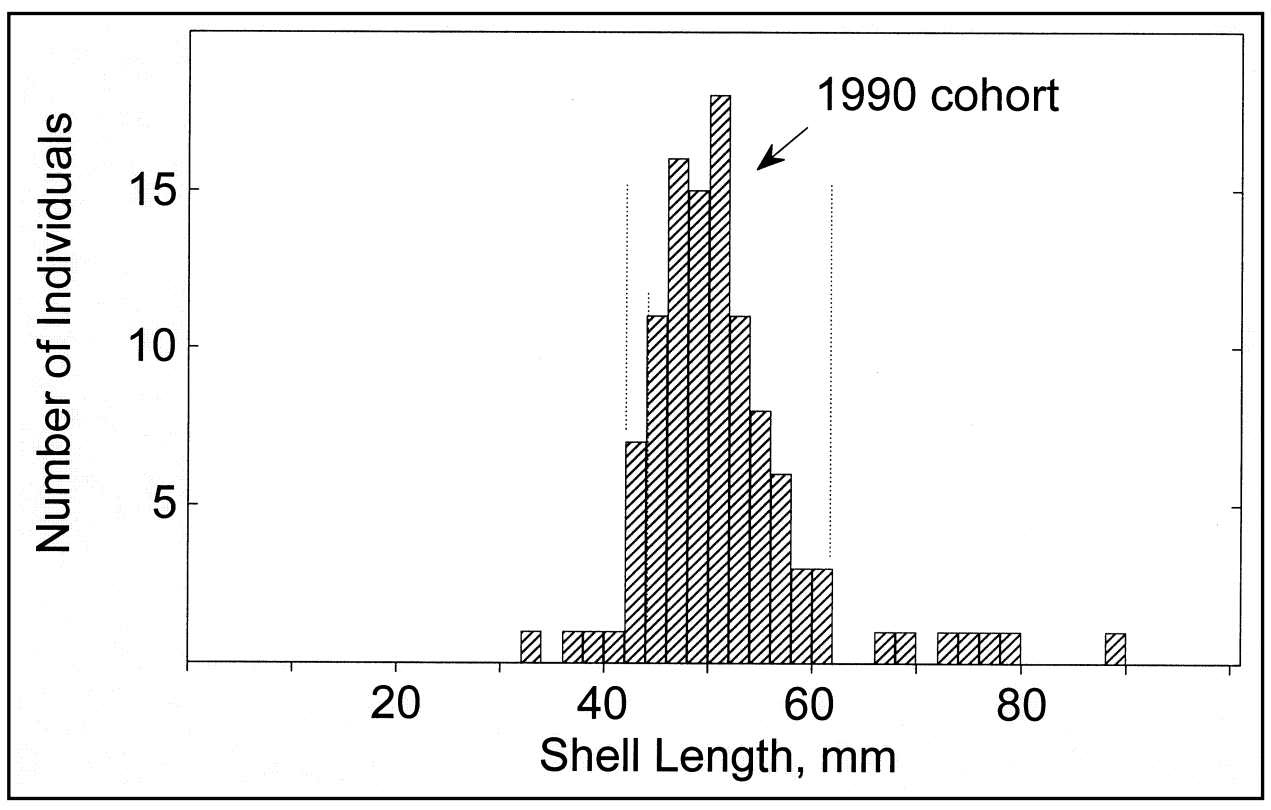

Figure 8. Heavy zebra mussel infestation of $F$. ebena, Sites $8 \mathrm{~N}$ and $8 \mathrm{~F}$

\section{Post Creek}

Quantitative studies. The relative abundance of Fusconaia ebena was much lower at Post Creek than at Olmsted. Among 154 unionids obtained from 30 quantitative samples at Post Creek, 83 (53.9 percent) were F. ebena (Tables 9 and 10). Quadrula pustulosa pustulosa (14.94 percent) was the next most abundant mussel. Ellipsaria lineolata (7.14 percent), Obliquaria reflexa (7.14 percent), Q. quadrula (5.20 percent), Q. metanevra (2.60 percent), and 


\section{Table 9}

Percent Abundance of Freshwater Mussels Collected Using Quantitative Methods in the Lower Ohio River Near Post Creek, 1999

\begin{tabular}{|c|c|c|c|c|}
\hline \multirow[b]{2}{*}{ Species } & \multicolumn{3}{|c|}{ Subsite Number } & \multirow[b]{2}{*}{ Total } \\
\hline & 1 & 2 & 3 & \\
\hline Fusconaia ebena & 15.00 & 60.49 & 58.49 & 53.90 \\
\hline Quadrula pustulosa pustulosa & 20.00 & 14.81 & 13.21 & 14.94 \\
\hline Ellipsaria lineolata & 20.00 & 6.17 & 3.77 & 7.14 \\
\hline Obliquaria reflexa & 5.00 & 8.64 & 5.66 & 7.14 \\
\hline Quadrula quadrula & 5.00 & 2.47 & 9.43 & 5.20 \\
\hline Quadrula metanevra & 0.00 & 1.23 & 5.66 & 2.60 \\
\hline Amblema plicata plicata & 20.00 & 0.00 & 0.00 & 2.60 \\
\hline Elliptio crassidens & 5.00 & 0.00 & 1.89 & 1.30 \\
\hline Cyclonaias tuberculata & 0.00 & 2.47 & 0.00 & 1.30 \\
\hline Truncilla truncata & 5.00 & 1.23 & 0.00 & 1.30 \\
\hline Potamilus alatus & 0.00 & 1.23 & 0.00 & 0.65 \\
\hline Leptodea fragilis & 0.00 & 0.00 & 1.89 & 0.65 \\
\hline Lampsilis cardium & 0.00 & 1.23 & 0.00 & 0.65 \\
\hline Quadrula nodulata & 5.00 & 0.00 & 0.00 & 0.65 \\
\hline Total individuals & 20 & 81 & 53 & 154 \\
\hline Total species & 9 & 10 & 8 & 14 \\
\hline$\%$ Ind $<30 \mathrm{~mm}$ & & & & 16.88 \\
\hline$\%$ Species $<30 \mathrm{~mm}$ & & & & 42.85 \\
\hline Menhinick's index & & & & 1.12 \\
\hline Shannon's diversity & & & & 1.64 \\
\hline Evenness & & & & 0.50 \\
\hline
\end{tabular}

\begin{tabular}{|c|c|c|c|c|}
\hline $\begin{array}{l}\text { Table } 10 \\
\text { Percent Occurrence } \\
\text { Quantitative Method } \\
\text { Illinois, } 1999\end{array}$ & $\begin{array}{l}\text { of } \mathrm{Fr} \\
\text { Is in } \mathrm{t}\end{array}$ & $\begin{array}{l}\text { er Mus } \\
\text { er Ohic }\end{array}$ & $\begin{array}{l}\text { ollect } \\
\text { Near }\end{array}$ & eek, \\
\hline & & Subsite & & \\
\hline Species & 1 & 2 & 3 & Total \\
\hline F. ebena & 30.00 & 100.00 & 90.00 & 73.33 \\
\hline Q. pustulosa & 30.00 & 80.00 & 50.00 & 53.33 \\
\hline E. lineolata & 40.00 & 50.00 & 20.00 & 36.67 \\
\hline O. reflexa & 10.00 & 50.00 & 30.00 & 30.00 \\
\hline Q. quadrula & 10.00 & 20.00 & 30.00 & 20.00 \\
\hline Q. metanevra & 0.00 & 10.00 & 20.00 & 10.00 \\
\hline A. plicata & 40.00 & 0.00 & 0.00 & 13.33 \\
\hline E. crassidens & 10.00 & 0.00 & 10.00 & 6.67 \\
\hline C. tuberculata & 0.00 & 20.00 & 0.00 & 6.67 \\
\hline T. truncata & 10.00 & 10.00 & 0.00 & 6.67 \\
\hline P. alatus & 0.00 & 10.00 & 0.00 & 3.33 \\
\hline L. fragilis & 0.00 & 0.00 & 10.00 & 3.33 \\
\hline L. cardium & 0.00 & 10.00 & 0.00 & 3.33 \\
\hline Q. nodulata & 10.00 & 0.00 & 0.00 & 3.33 \\
\hline Total samples & 10 & 10 & 10 & 30 \\
\hline
\end{tabular}


Amblema plicata plicata (2.60 percent) were common. A total of 14 species were represented in quantitative samples at Post Creek. Recent recruits $(<30 \mathrm{~mm}$ long) composed 17 percent of the community. Six species showed some evidence of recent recruitment despite the relatively small sample of species other than F. ebena. Diversity and evenness were moderate. The ShannonWeaver Index equaled 1.64 and Menhinick's index equaled 1.12. Evenness equaled 0.50 .

Although mussel diversity was greater at Post Creek than Olmsted, density was lower. Average mussel density ranged from 8 individuals per $\mathrm{m}^{2}$ at Site 1 to 32 individuals per $\mathrm{m}^{2}$ at Site 2; density at Site 3 averaged 21 individuals per $\mathrm{m}^{2}$. Overall, density of native mussels at Post Creek was approximately 35 percent of the density observed at Olmsted.

Size structure of the F. ebena population at Post Creek (Figure 9) was strikingly similar to that at Olmsted (Figure 1). Individuals at Post Creek ranged from 12 to $76 \mathrm{~mm}$; the slightly smaller length range relative to Olmsted almost certainly reflected the much smaller sample from Post Creek. The cohort of individuals ranging from 46 to $70 \mathrm{~mm}$ (1990 recruits) heavily dominated the population. Due to the relatively small sample, the 1981 cohort was not clearly distinguishable at Post Creek. The minor cohort of 1997 recruits clearly evident at Olmsted was also evident at Post Creek.

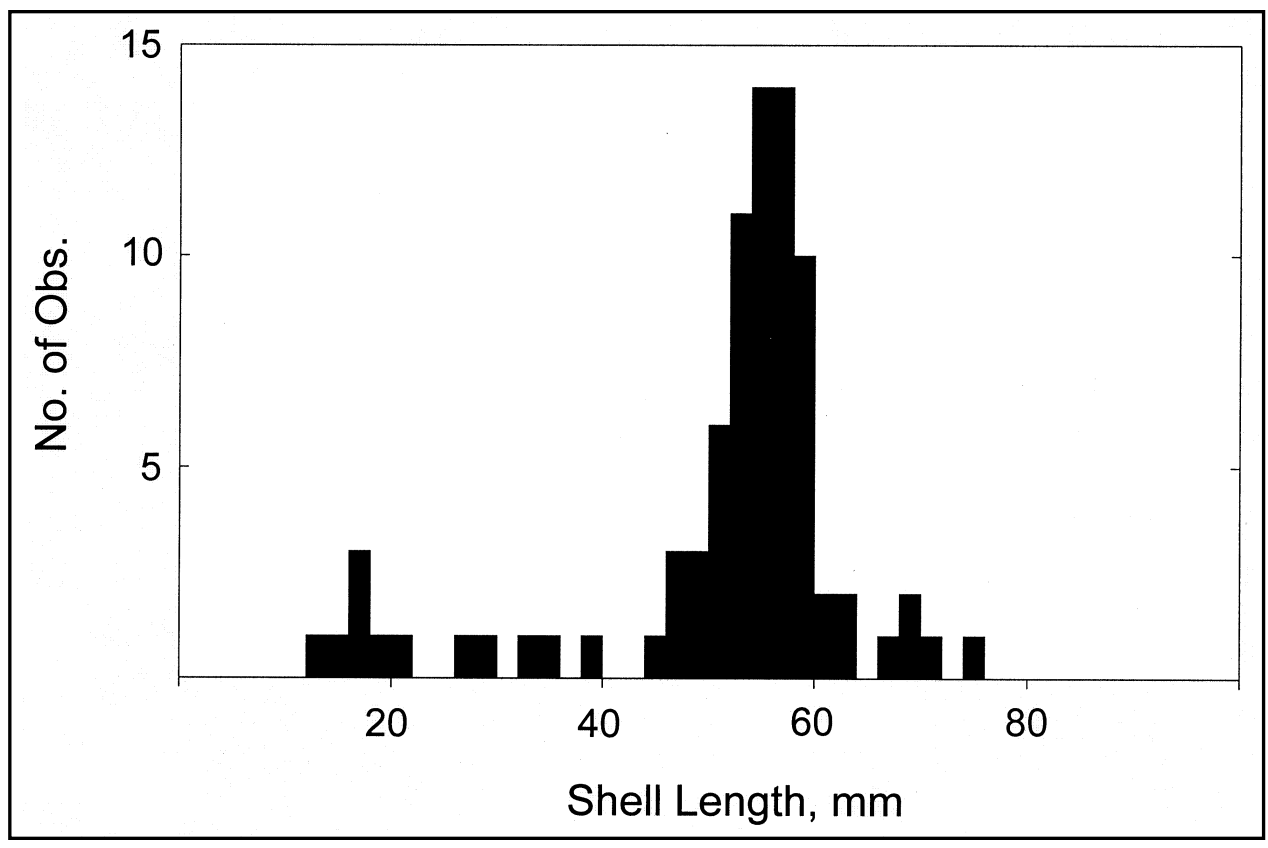

Figure 9. Population size structure, F. ebena, Post Creek, 31 July 1999 
Qualitative studies. A total of 452 individuals and 14 species were collected by qualitative methods at Post Creek (Table 11). Fusconaia ebena was much more abundant farshore than nearshore. Indeed, Q. p. pustulosa was slightly more abundant than $F$. ebena in the nearshore samples. The farshore community was more typical than the nearshore of that generally encountered in gravelly substratum in the lower Ohio River $-F$. ebena composed 62 percent of the farshore community. Most species were locally uncommon; 6 of 14 species collected at the farshore location individually composed less than 1 percent of the community.

\section{Table 11 \\ Percent Abundance and Occurrence of Mussels Collected by Qualitative Methods at Post Creek, 1999}

\begin{tabular}{||l|l|l||}
\hline \multirow{2}{*}{ Species } & \multicolumn{2}{|c||}{ Percent Abundance } \\
\cline { 2 - 3 } & Nearshore & Farshore \\
\hline \hline Fusconaia ebena & 26.81 & 62.42 \\
\hline Quadrula pustulosa pustulosa & 32.61 & 10.83 \\
\hline Ellipsaria lineolata & 10.14 & 9.87 \\
\hline Amblema plicata plicata & 10.14 & 1.27 \\
\hline Quadrula quadrula & 6.52 & 2.55 \\
\hline Quadrula metanevra & 1.45 & 4.78 \\
\hline Obliquaria reflexa & 2.90 & 2.55 \\
\hline Elliptio crassidens & 4.35 & 1.59 \\
\hline Cyclonaias tuberculata & 1.45 & 0.96 \\
\hline Quadrula nodulata & 0.72 & 0.96 \\
\hline Potamilus alatus & 0.72 & 0.96 \\
\hline Megalonaias nervosa & 0.72 & 0.32 \\
\hline Leptodea fragilis & 0.00 & 0.64 \\
\hline Obovaria olivaria & 0.00 & 0.32 \\
\hline Lampsilis cardium & 0.72 & 0.00 \\
\hline Ligumia recta & 0.72 & 0.00 \\
\hline & 14 & 14 \\
\hline & 138 & 314 \\
\hline \hline
\end{tabular}

Corbicula fluminea. Size structure of the $C$. fluminea population at Post Creek (Figure 10) was virtually identical to that at Olmsted (Figure 3); density was substantially higher at Post Creek than at Olmsted. The same cohort of small individuals that composed the entire population sample from Olmsted heavily dominated the sample from Post Creek - approximately 95 percent of the population at Post Creek was represented by individuals ranging from 7 to $17 \mathrm{~mm}$. However, there was evidence of an additional minor cohort of larger individuals; 7 mussels ranging from 21 to $29 \mathrm{~mm}$ represented this larger sized cohort. 


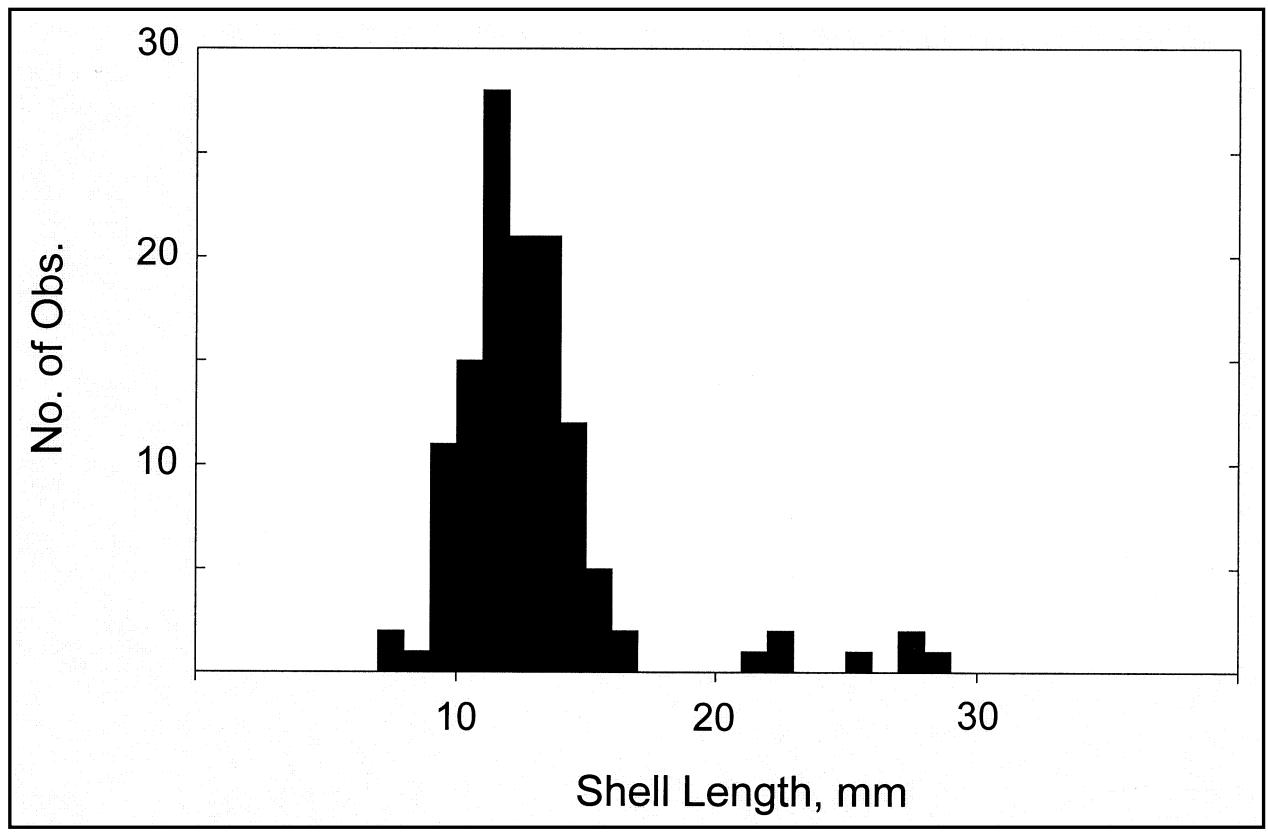

Figure 10. Population size structure, C. fluminea, Post Creek, 31 July 1999

Density of Corbicula at Post Creek was low (ranging from 4 to 32 individuals per $\mathrm{m}^{2}$ ) but approximately 4-5 times greater than at Olmsted. The larger sample from Post Creek relative to Olmsted is likely to have been caused by inclusion of the few individuals of the older cohort at Post Creek but not Olmsted.

Dreissena polymorpha. Dreissena polymorpha at Post Creek were more dense than the population at Olmsted but had the same size structure (Figure 11). The considerably lower abundance of the cohort of largest mussels at Post Creek (Figure 11) versus Olmsted (Figure 4) may indicate a recruitment or survival difference between these locations. Several D. polymorpha greater than $20 \mathrm{~mm}$ long were present at Olmsted, but few such large individuals were present at Post Creek.

\section{Discussion}

The nearshore limit of the Olmsted mussel bed occurs at approximately el 278 to 280 (Payne and Miller 1997) and reflects historical patterns of extremely low river stage. During the winter of 1980/1981 and the summer and fall of 1988, the 279 -ft elevation contour of the shoal was exposed to air for at least 14 consecutive days, enough to kill many unionids. The 281 -ft elevation was exposed for maximum periods of 25,35 , and 59 consecutive days in the fall of 1976, winter of 1980/1981, and summer of 1988, again, enough to kill most unionids. Thus, it is not surprising that native mussel density is quite low nearshore of the 279-ft elevation contour. 


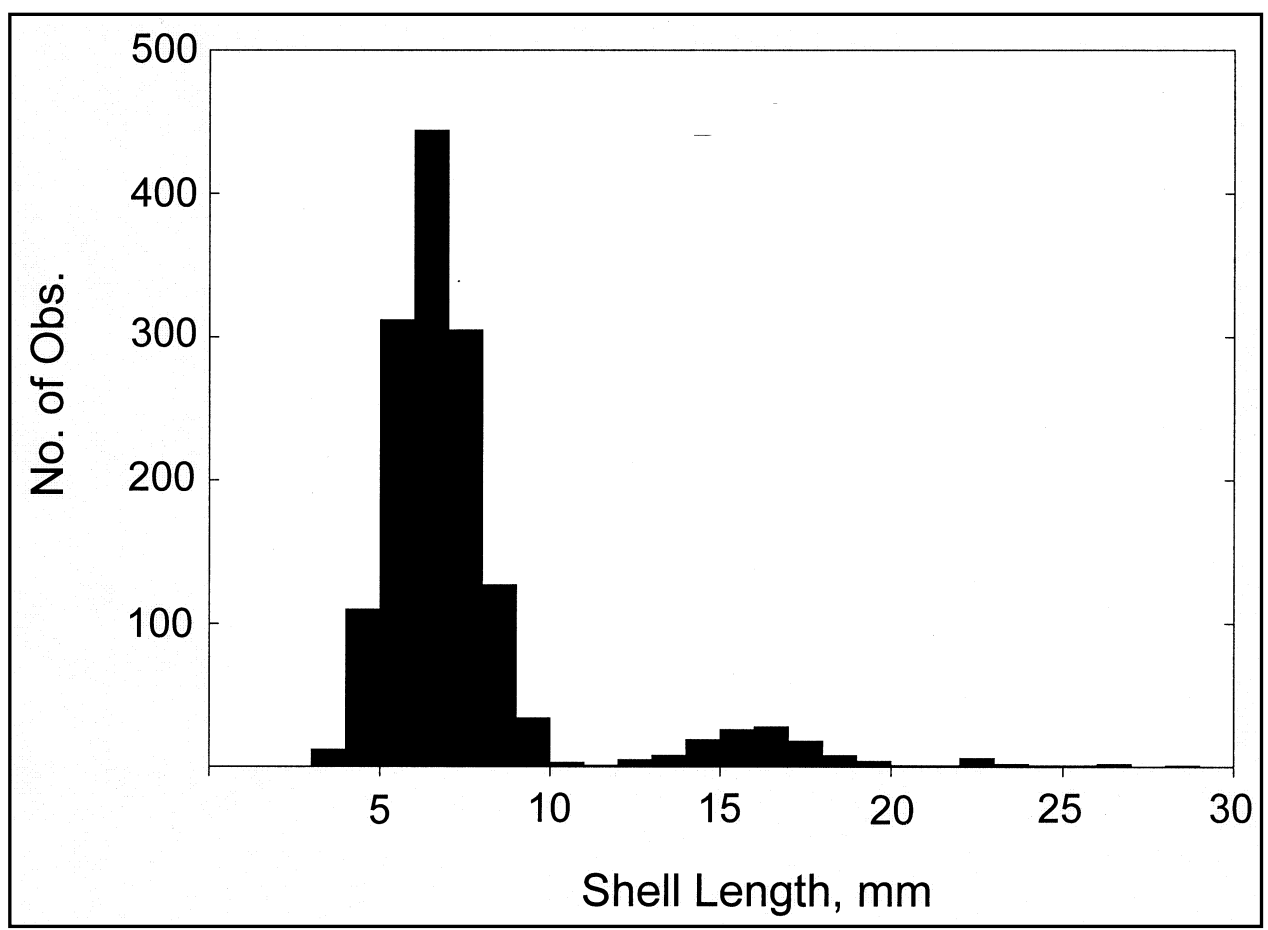

Figure 11. Population size structure, D. polymorpha, Post Creek, 31 July 1999

The farshore limit of the mussel bed occurs at approximately el 267 . This limit is less distinct than the nearshore boundary and reflects lack of suitably stable sand and gravel. Increasingly erosional conditions cause scoured sand and bedrock to be the predominant substratum farshore of el 267. However, isolated patches of somewhat more stable substratum (sand or sand and gravel) are occasionally encountered farshore of el 267 that support dense assemblages of mussels. In addition, patches of sand that may not be stable for more than a few years can provide temporarily suitable substratum for recent recruits. A lack of large, old mussels in such patches suggests that such substratum and mussels are eventually swept away by scouring flows, preventing the establishment of a complex age structure in mussel assemblages encountered much nearer shore of el 267 (Payne and Miller 1998).

Within the mussel bed, there is a high degree of variability in mussel density. In general, substratum type is not clearly correlated with mussel density between the el 279 and 267 contours (Payne and Miller 1998) except that erosional patches of sand or bedrock obviously do not support mussels. Patchiness of mussel density is apparent among quadrats within sites as well as among sites. Both a high degree of sample replication (i.e., at least 10 quadrats per site) and some degree of site replication (at least two closely adjacent subsites per site) are required to establish if location-specific estimates of density are to be confidently compared to establish spatial patterns of density distribution. Although densities of 200-300 individuals per $\mathrm{m}^{2}$ are occasionally encountered, these are outlier data and always are due to extremely dense clusters of recent recruits (especially F. ebena). A density range of 50 to 100 individuals per $\mathrm{m}^{2}$ is more likely to correspond to "local carrying capacity" with respect to a complex, age-structured assemblage. 
Fusconaia ebena heavily dominates mussels in the stable shoals of the lower Ohio River. Despite being a species-rich community (with 32 species (Payne and Miller 1997)), the mussel bed at Olmsted has low diversity in terms of the Shannon or Menhinick's indices. This is a mathematical consequence of the high relative abundance of the dominant species. The community at Post Creek is similarly rich in species, but $F$. ebena is much less heavily dominant than at Olmsted. Thus, diversity indices for the Post Creek community indicate moderate diversity. In a broad sense, in which diversity simple equals richness, the lower Ohio River community is indeed diverse at both Olmsted and Post Creek.

Good recruitment appears to be a community-wide phenomenon at Post Creek and Olmsted. The 1990 cohort of $F$. ebena is exceptionally abundant at both locations. However, one or a few individuals of less than $30-\mathrm{mm}$ length have been recovered of nearly all species present on the bed. Obviously, the rarest species yield so few individuals that it is possible to miss recent recruits of those taxa even if they exist.

Native mussels in the lower Ohio River, including F. ebena, have been resilient to growth of high-density populations of nonindigenous bivalves. The first such species invasion was by the Asian clam, $C$. fluminea. A dense population of this species in the lower Ohio River was first observed in 1957 (Sinclair and Isom 1961; McMahon 1983). Sampling by the authors at Olmsted began in 1983. From 1983 to 1993 C. fluminea was very dense (typically 1,000 to 3,000 individuals per $\mathrm{m}^{2}$ ) and populations were characterized by complex age and size structure (typically three to five cohorts) with the oldest and largest individuals being 2 to 3 years old and 30 to $40 \mathrm{~mm}$ long. Despite sustained high density and complex demography of $C$. fluminea, the authors found no correlation between native mussel and $C$. fluminea density within the Olmsted bed (Miller and Payne 1988). A negative relationship would have been evidence of competition between these taxa. Since 1993, C. fluminea density has greatly declined, and the population now has simple age structure (typically one or two cohorts) and includes few individuals greater than $15 \mathrm{~mm}$ long.

Dreissena polymorpha first appeared in the lower Ohio River in 1991 (Payne, Miller, and Shafer 1994), and has replaced C. fluminea as the dense nonindigenous bivalve existing with native mussels. However, only the 1994 generation of $D$. polymorpha has been extremely dense $(49,000$ individuals per $\mathrm{m}^{2}$ in September 1994 to 5,000 individuals per $\mathrm{m}^{2}$ in July 1995). This dense cohort heavily infested native mussels in 1994 and early 1995, resulting in reduced unionid growth (Payne and Miller 1998), but has not caused major declines in density such as have been reported in the Great Lakes. High density of D. polymorpha has not been sustained in the lower Ohio River. Cohorts since the 1994 year class have not been especially dense. It remains to be seen if D. polymorpha can occur in sustained abundance in the lower Ohio River at a density sufficiently high to have drastic effects on native bivalves. The most evident effect in the lower Ohio River since 1991 has been suppressed unionid growth during periods of high $D$. polymorpha density or during periods of low or moderate density at sites with locally high density. 
The demography of $D$. polymorpha populations at both Olmsted and Post Creek in late July 1999 was characteristic of a stable, complex age structure. The smallest and youngest cohort, centered at 5 to $9 \mathrm{~mm}$ and probably representing 1999 recruitment, was the most abundant. The next larger cohort, centered at 14 to $18 \mathrm{~mm}$ and probably representing 1998 recruitment, was much less abundant. Finally, the cohort of largest mussels, centered at 22 to $28 \mathrm{~mm}$ and probably representing 1997 recruitment, was even less abundant. Density was moderately high at both Olmsted and Post Creek. Multiple cohorts, decreased abundance with age, and moderate to high density, if sustained for several years, would indicate a stable and complexly age structured population of $D$. polymorpha in the lower Ohio River. 


\section{Population Dynamics of Fusconaia ebena}

\section{Site and Methods}

Demographically complete samples of $F$. ebena were obtained at Olmsted in summer or fall of 1983 through 1999 by having divers excavate substratum from $0.25-\mathrm{m}^{2}$ quadrats. Replicate samples (usually ten) were always taken from multiple sites (usually two to four) in a central portion of the mussel bed (Table 12), except in 1993 when the objective was to map the boundaries of the bed and there was no concentration of sampling in a central location (Payne and Miller 1997). Thus, 1993 results are compared with those of other years with respect to demography but not density. Mussels were sorted in the field after sampled substratum was taken to shore and washed through a series of sieve screens, except in 1983 when mussels were sorted from unsieved substratum in white enamel pans. The square mesh of the smallest sieve screen had a diagonal aperture of $6.4 \mathrm{~mm}$. The greatest anterior-posterior dimension across the valves (shell length) of each $F$. ebena was measured to the nearest $0.1 \mathrm{~mm}$ using calipers. Length-frequency histograms were constructed for composites of each year's sample of $F$. ebena using 2-mm class intervals over a length range typically from 10 to $90 \mathrm{~mm}$. Mussels were returned to the shoal after measurement except for a few specimens kept as voucher material, for dry mass measurements (Payne and Miller 1989), or for use in laboratory studies (Payne and Miller 1987).

Daily estimates of river discharge (United States Geological Survey annual records) from April through July were compiled for 1977 through 1997 and compared to annual variation in mussel recruitment. Discharge of both the lower Ohio River and upper Mississippi River affects hydraulic conditions at the lower Ohio River mussel bed, as the confluence of these two large rivers is only $23 \mathrm{~km}$ downstream of the bed. Thus, discharge records were analyzed for both the lower Ohio River and upper Mississippi River.

\section{Mussel and Fish Relationship}

Both F. ebena and the fish Alosa chrysochloris inhabit large rivers and prefer moderately swift water and stable sandy or gravelly shoals (Cummings and Mayer 1992; Wallus, Yeager, and Simon 1990; Surber 1913). 


\begin{tabular}{|c|c|c|c|c|}
\hline \multirow[b]{2}{*}{ Date } & \multirow{2}{*}{$\begin{array}{l}\text { Number of } \\
\text { quadrats }\end{array}$} & \multirow{2}{*}{$\begin{array}{l}\text { Number of } F \\
\text { ebena }\end{array}$} & \multicolumn{2}{|c|}{ Individuals per $0.25 \mathrm{~m}^{2}$} \\
\hline & & & Mean & SD \\
\hline 29 Sep 1983 & 24 & 256 & 10.7 & 5.3 \\
\hline 31 Oct 1985 & 17 & 269 & 15.8 & 6.5 \\
\hline 29 Sep 1987 & 20 & 219 & 11.0 & 4.8 \\
\hline 23 Sep 1990 & 30 & 267 & 8.9 & 4.6 \\
\hline 1 Oct 1991 & 20 & 136 & 6.8 & 3.4 \\
\hline 26 Aug 1992 & 40 & 628 & 15.7 & 8.3 \\
\hline 2 Sep 1993 & 46 & 973 & $-{ }^{1}$ & $-{ }^{1}$ \\
\hline 31 Aug 1994 & 40 & 1,194 & 29.9 & 12.5 \\
\hline 20 Jul 1995 & 40 & 632 & 15.8 & 15.9 \\
\hline 12 Aug 1996 & 50 & 504 & 10.1 & 10.2 \\
\hline 8 Aug 1997 & 30 & 237 & 7.9 & 5.2 \\
\hline 9 Aug 1998 & 40 & 1,072 & 26.8 & 11.8 \\
\hline 30 Jul 1999 & 60 & 840 & 14.0 & \\
\hline
\end{tabular}

Glochidia of $F$. ebena must attach to gills of A. chrysochloris for successful transformation to the benthic juvenile stage (Coker et al. 1921; Surber 1913). Not surprisingly, therefore, the geographic distribution of the mussel is entirely within that of the fish. Both are common in large rivers draining into the lower and middle Mississippi River system, including the Ohio and many of its principal tributaries (Etnier and Starnes 1993; Cummings and Mayer 1992; Miller and Payne 1992; Wallus, Yeager, and Simon 1990; Payne and Miller 1989; Robinson and Buchanan 1988). Although highly migratory and occasionally found in brackish water in rivers draining into the Gulf of Mexico, A. chrysochloris is not anadramous (Lee et al. 1980). Resident populations occur upstream of high-lift dams on the Ohio, Tennessee, Cumberland, and Arkansas Rivers (Wallus, Yeager, and Simon 1990; Robinson and Buchanan 1988). Indeed, locks and dams in the Arkansas River, although imposing to fish migration, deepened the river channel, reduced suspended solids, and apparently improved habitat for A. chrysochloris (Robinson and Buchanan 1988).

Adult $A$. chrysochloris make prominent upstream runs to spawn over rocky or gravelly shoals in spring or early summer (Wallus, Yeager, and Simon 1990). Release of glochidia conglutinates by $F$. ebena during such spawning aggregations of $A$. chrysochloris is likely to enhance successful parasitism of fish (Kat 1984). Alosa chrysochloris used to be common in the upper Mississippi River, where $F$. ebena once dominated native unionids in main channel shoals (Theler 1987). A hydroelectric dam built at Keokuk, IA, in 1913 prevented upstream migration and led to extirpation first of A. chrysochloris and more gradually of F. ebena (Theler 1987; Lee et al. 1980; Coker 1914). Spring and summer migrations must have been required for A. chrysochloris to spawn in the upper Mississippi River; in this northernmost extension of the range of the species, overwintering was apparently not possible. Both A. chrysochloris and 
F. ebena remain common, with the latter often dominant among mussels, in runof-river reservoirs in more southerly portions of the range of the fish.

\section{Annual Variation in Recruitment}

Average density of $F$. ebena at Olmsted has ranged from 7 to 30 individuals per $0.25 \mathrm{~m}^{2}$ from 1983 to 1999 (Figure 12). Demography of the lower Ohio River population of $F$. ebena has been characterized by extreme dominance of only two year classes-1981 and 1990 (Figure 13). Seventy-one percent of the population in 1983 was composed of a single cohort (1981) of recent recruits. In 1992, the 1990 year class composed 85 percent of the population (see Payne and Miller 2000 for a more detailed discussion).

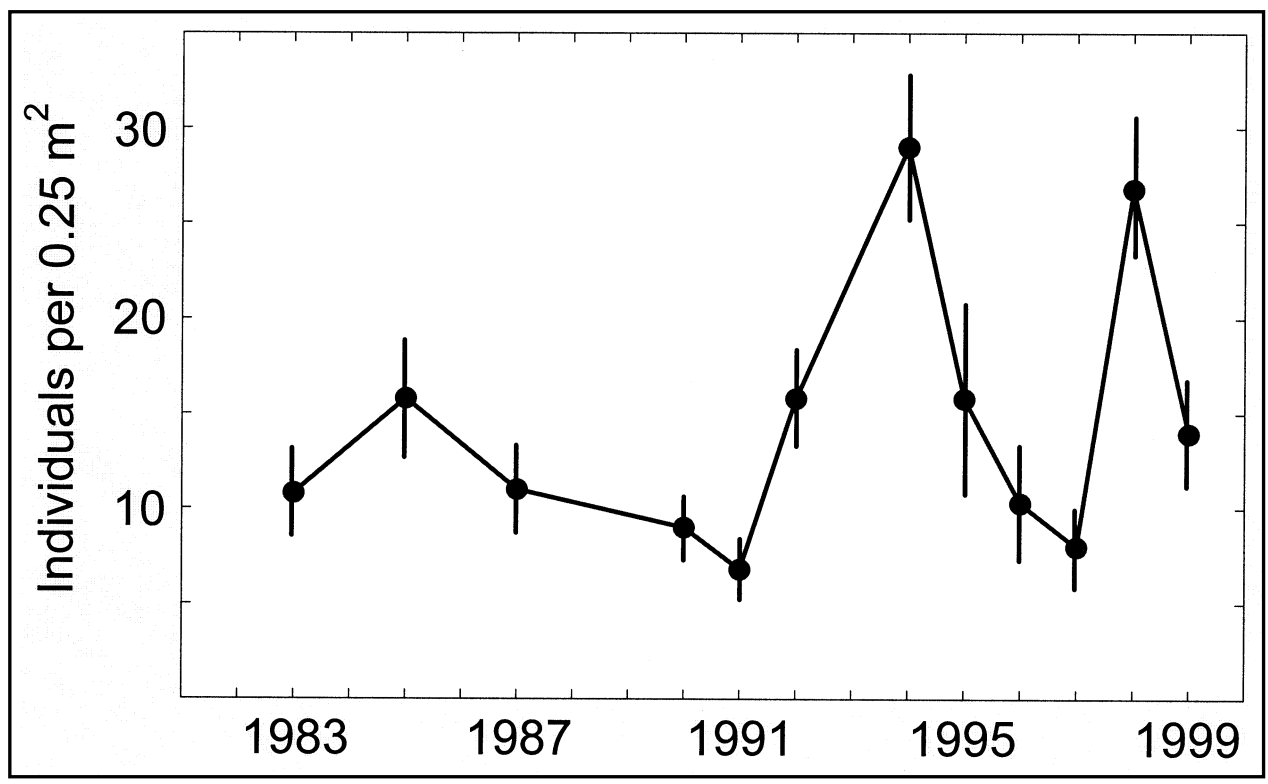

Figure 12. Density of $F$. ebena, lower Ohio River at Olmsted

Minor abundance of several year classes other than 1981 and 1990 was evident (Figure 13). Years characterized by minor but evident recruitment include 1979, 1984, and 1985. More recently, 1995 and 1997 were years with substantial recruitment (albeit much less strong than 1981 or 1990). In 1997, a substantial number of individuals less than $20 \mathrm{~mm}$ long were collected; these individuals probably represent mostly 1995 recruitment. Similarly, a minor cohort of mussels with average length of $19 \mathrm{~mm}$ in 1999 probably represent 1997 recruitment. The same cohort had an average length of approximately $10 \mathrm{~mm}$ in 1998.

Thus, long-term monitoring provided evidence of two extremely strong year classes (1981 and 1990) and several minor year classes (possibly 1979, 1982, 1984, 1985, 1993, 1994, 1995, and 1997) of F. ebena population in the lower Ohio River. The 9-year separation and extremely high relative abundance of the 1981 and 1990 cohorts allowed estimation of $F$. ebena growth rate directly from the series of length-frequency histograms. 


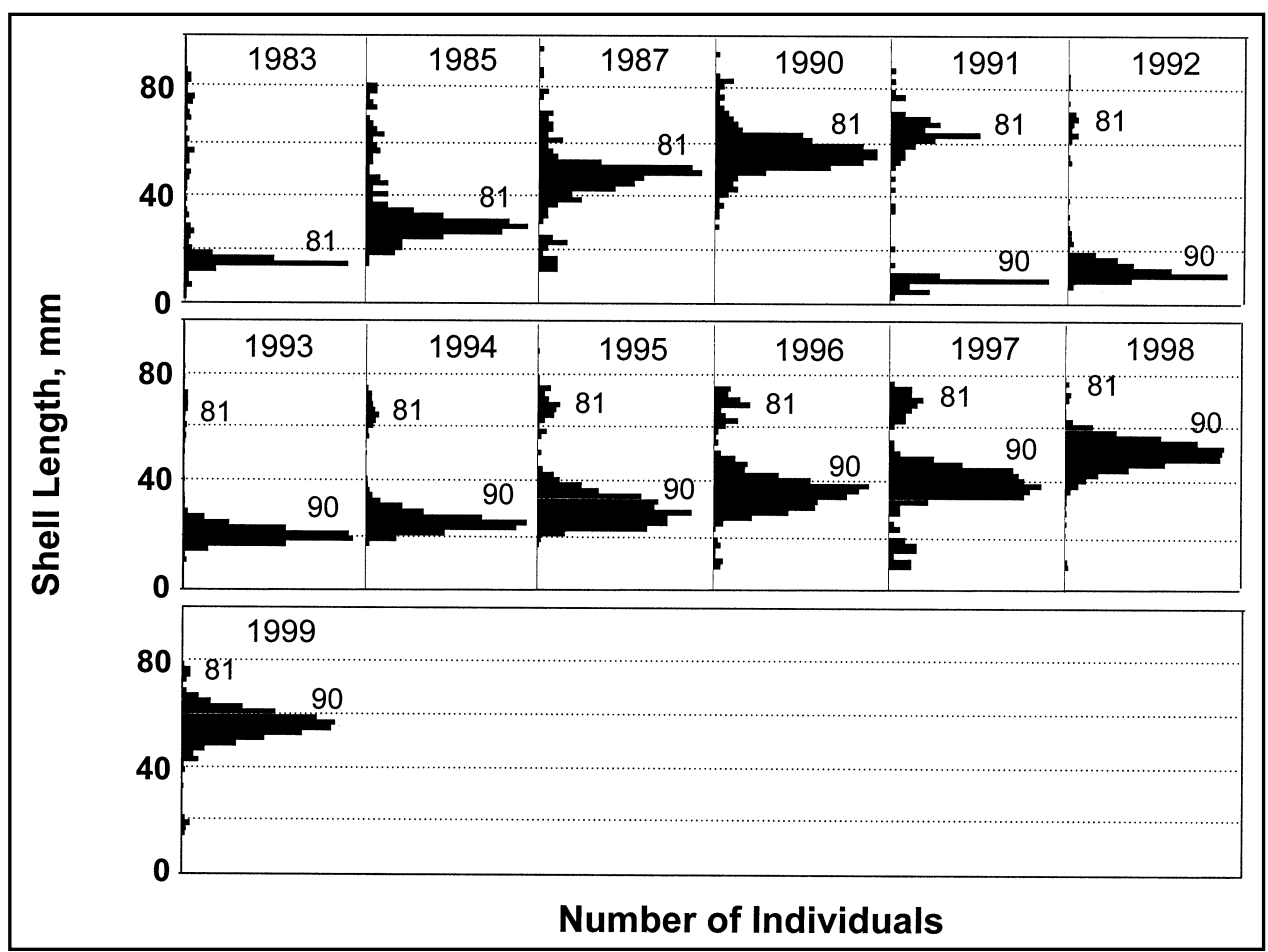

Figure 13. Demography of the lower Ohio River population of $F$. ebena

\section{Growth and Survival}

In any population of long-lived individuals, decreased growth rate with increased age and size causes overlap of individuals of adjacent cohorts, tending to obscure upper and lower size limits of a particular year class. For example, the recent recruits ranging from 12 to $26 \mathrm{~mm}$ in 1987 were difficult to discern in the lower tail of the length distribution of the dominant 1981 cohort in 1990 (Figure 13). Regardless of such difficulties, central tendency in size distribution of the two dominant year classes usually was apparent (Figure 13).

Growth rates were calculated using average lengths estimated for the 1981 and 1990 cohorts. Averages were based on size class intervals near the modal length of individuals per cohort. Mussels falling in class intervals near the upper and lower size limits of each cohort were omitted. These omissions had virtually no effect on averages due to low relative abundance of mussels in near-boundary size classes. The best representation of $F$. ebena growth through age 18 was provided by two linear regressions of shell length (SL, $\mathrm{mm}$ ) on age (A, years) (Figure 14). The first model, applicable to ages 2 through 10 years, was $\mathrm{SL}=$ $2.59+6.03 \mathrm{~A} ; r^{2}=0.96 ; p<0.0001$. Despite minor intercohort differences, this model fit both the 1981 and 1990 cohorts. The 1990 cohort was slightly smaller than the 1981 cohort from ages 4 to 7 years, probably due to a temporarily severe infestation of D. polymorpha from 1994 through 1995 (Payne and Miller 1998). However, above-average growth of the 1990 cohort was evident from age 7 through 8 years. Furthermore, the 1981 cohort showed below-average growth 


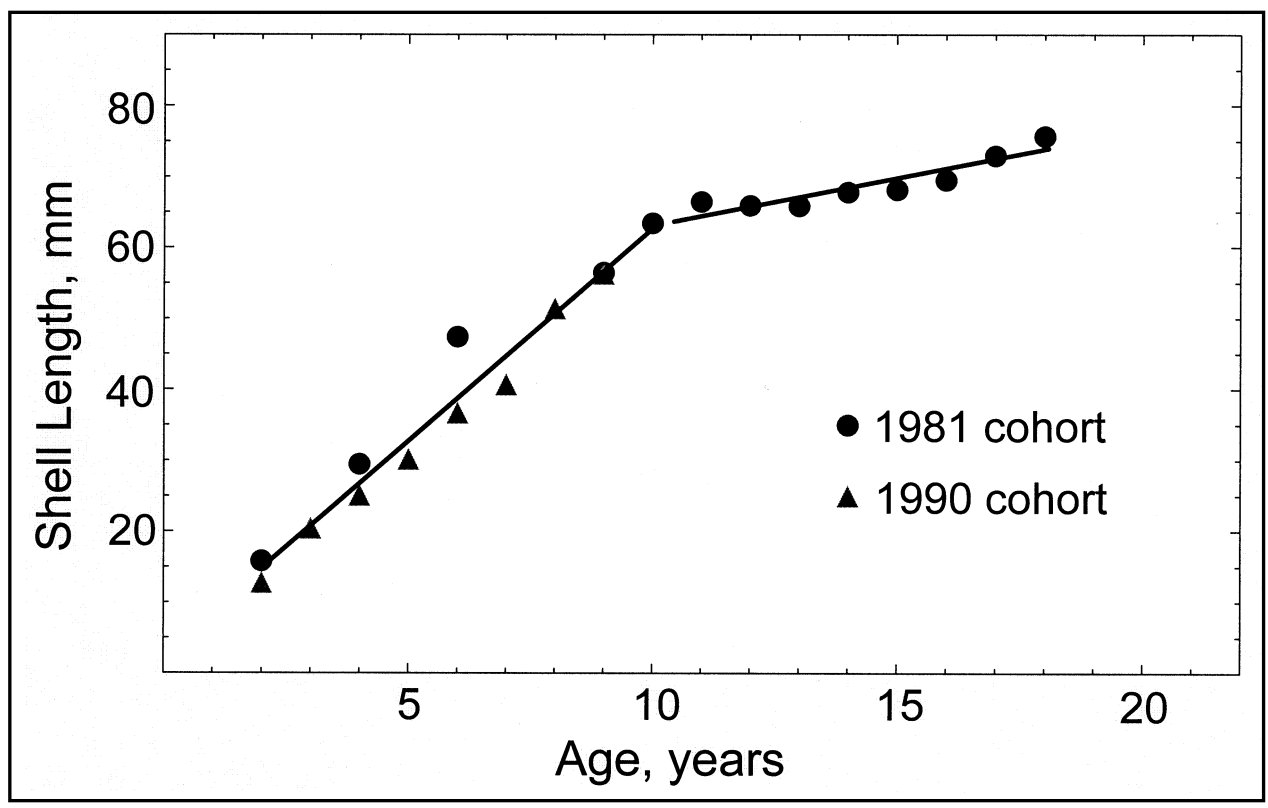

Figure 14. Linear regression of $F$. ebena shell length on age

from age 6 through 9 years. Overall, the single linear regression indicating annual growth of $6.0 \mathrm{~mm}$ provided an excellent fit for both cohorts from ages 2 through 10 years.

Growth from ages 10 through 18 years was much slower, with data available only for the 1981 cohort. The linear model applied to these ages was $\mathrm{SL}=50.2+$ $\left.1.30 \mathrm{~A} ; r^{2}=0.87 ; p<0.0002\right)$. The poorer fit of this model relative to that for early growth reflected both slow growth and low relative abundance of the 1981 cohort from 1993 through 1998.

A survivorship curve was based on the declining density of the 1981 cohort from 1983 through 1999 (Figure 15). This curve indicates a constant proportion (18.4 percent) of the cohort died each year from age 2 through 18 years. Cumulative mortality from 1983 to 1999 was 96 percent, as density declined from 14.7 to 0.6 individuals per $0.25 \mathrm{~m}^{2}$.

\section{Annual Variation in Hydraulic Conditions}

Average discharge of the lower Ohio River is $7,646 \mathrm{~m}^{3} \mathrm{~s}^{-1}$ with considerable seasonal variation (Figure 16). Depositional conditions and low discharge $\left(<5,000 \mathrm{~m}^{3} \mathrm{~s}^{-1}\right)$ tend to occur from July through October while erosional conditions and high discharge $\left(>10,000 \mathrm{~m}^{3} \mathrm{~s}^{-1}\right)$ occur from December through April (Figure 16). The tendency for deposition due to a backwater effect near the confluence of the lower Ohio River and upper Mississippi River is greater than that due to low lower Ohio River discharge alone if upper Mississippi River discharge is simultaneously and substantially higher. 


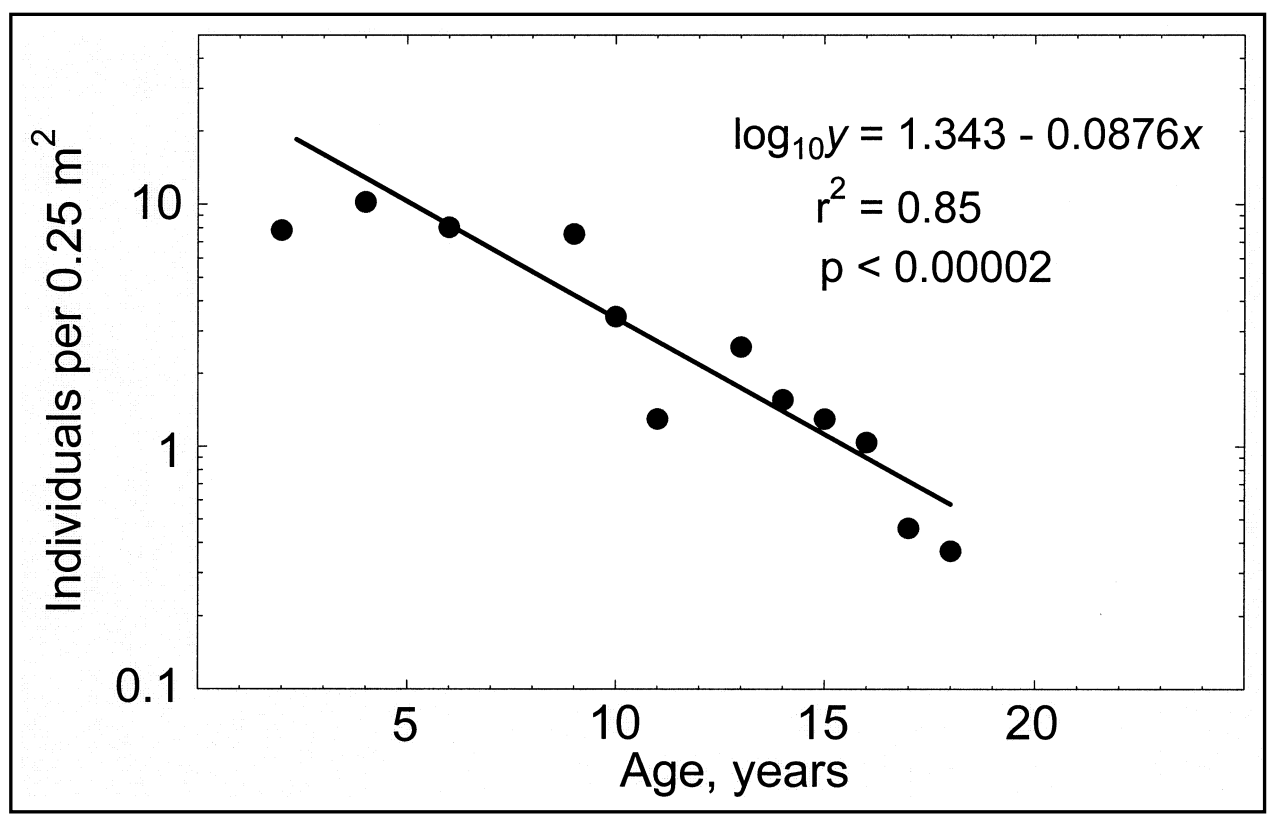

Figure 15. Survivorship curve, 1981 F. ebena cohort, 1983-1999

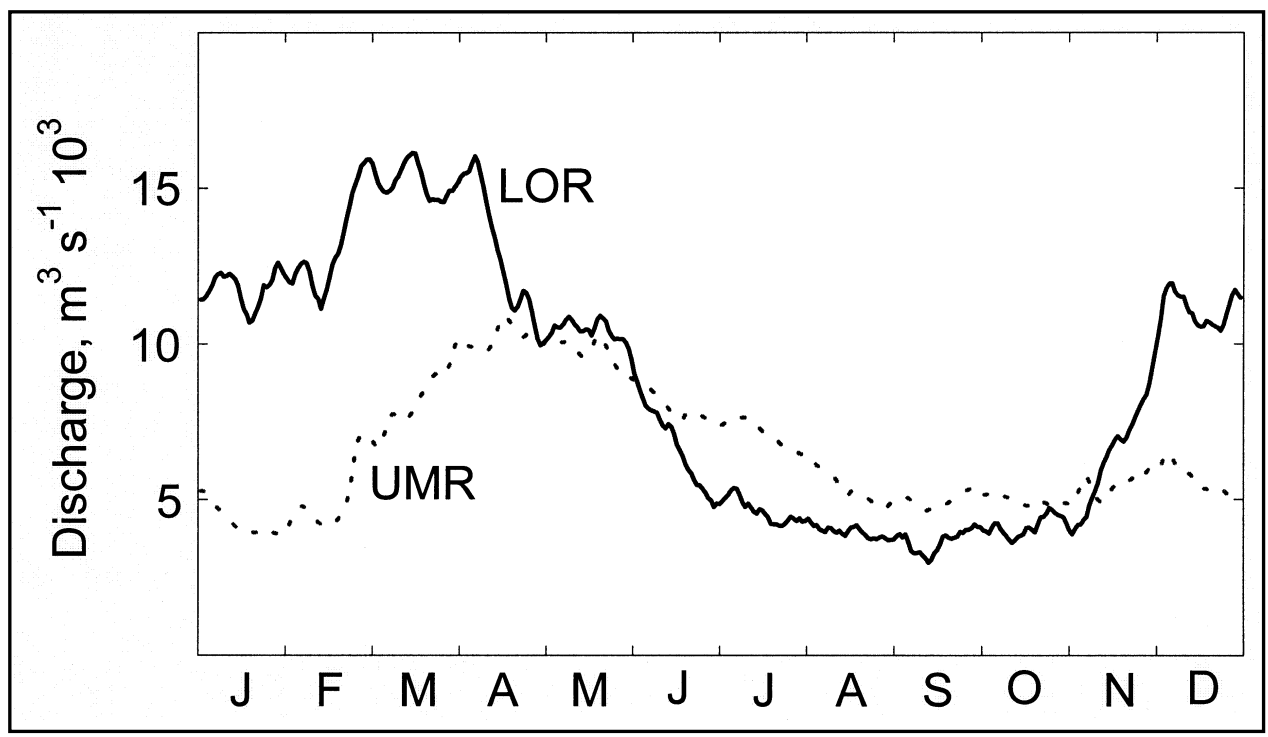

Figure 16. Annual discharges of lower Ohio River (LOR) and upper Mississippi River (UMR)

Discharge from April through July was of special interest with respect to $F$. ebena recruitment. Water temperature in the lower Ohio River typically rises from $10{ }^{\circ} \mathrm{C}$ to the average seasonal maximum of $28^{\circ} \mathrm{C}$ from April through July (Figure 17). This period of rapid water temperature rise to the summer maximum almost certainly includes $F$. ebena population peaks in fertilization, glochidia release, and juvenile settlement (Coker et al. 1921) as well as the peak spawning period of A. chrysochloris (Wallus, Yeager, and Simon 1990). 


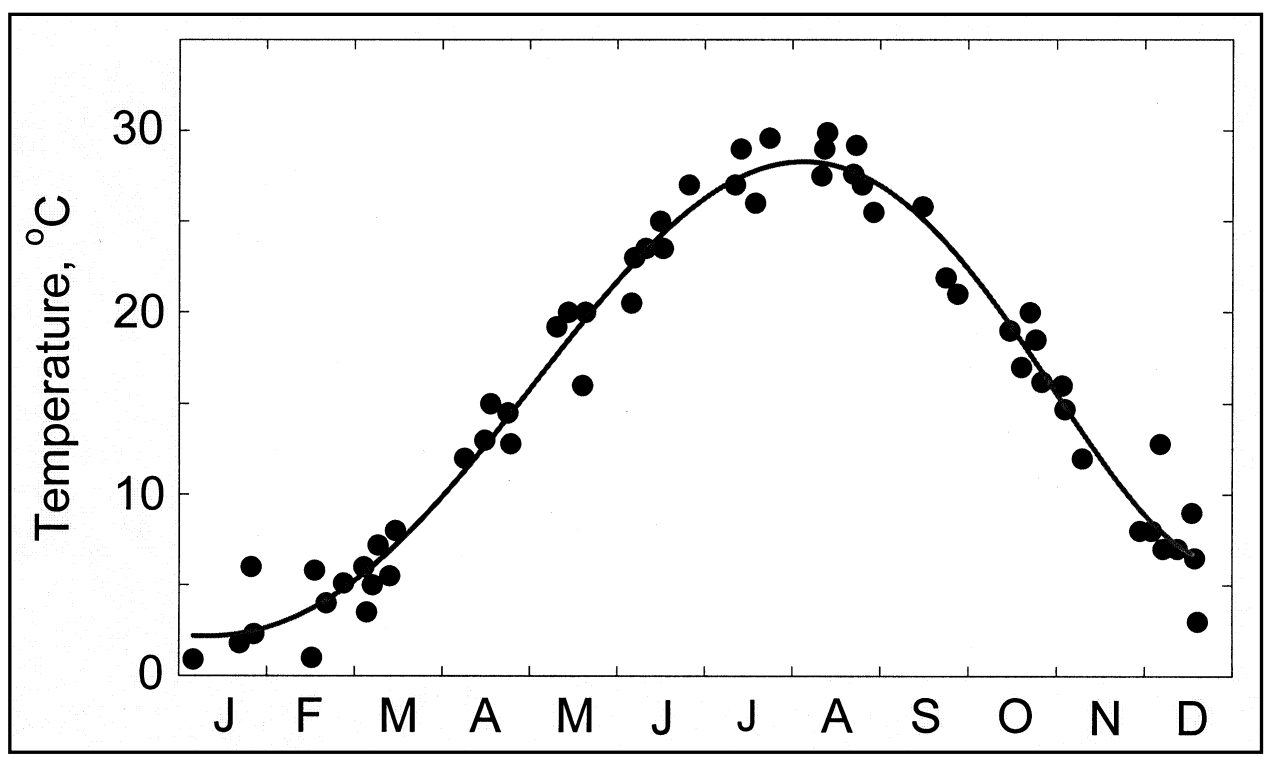

Figure 17. Annual lower Ohio River water temperature

Comparison of April through July discharge patterns revealed that hydraulic conditions in the lower Ohio River were complex, and remarkably similar during this period in 1981 and 1990 (Figure 18). In both years, discharge was approximately $6,000 \mathrm{~m}^{3} \mathrm{~s}^{-1}$ in early April, rose rapidly to $11,000 \mathrm{~m}^{3} \mathrm{~s}^{-1}$ by late April, and dropped rapidly to $6,000 \mathrm{~m}^{3} \mathrm{~s}^{-1}$ in early May. Then, discharge rose rapidly to $14,000 \mathrm{~m}^{3} \mathrm{~s}^{-1}$ by mid-May and $19,000 \mathrm{~m}^{3} \mathrm{~s}^{-1}$ by mid-June, but plummeted to $2,000 \mathrm{~m}^{3} \mathrm{~s}^{-1}$ by late June (1990) or 4,000 $\mathrm{m}^{3} \mathrm{~s}^{-1}$ by early July (1981). Analyzing 1977 to 1996 records of discharge, Payne and Miller (2000) showed that this discharge pattern characterized 1981 and 1990 but was only somewhat similar to patterns in a few other years (1983, 1984, 1995, and 1996). Three of those years (all except 1983) also appeared to be years with substantial recruitment, albeit minor relative to 1981 and 1990. In 1999, evidence of minor yet substantial 1997 recruitment was observed. The April through July discharge pattern in 1997 was reasonably similar to that of 1981 and 1990 (Figure 19). Except for being shifted forward in time by about 1-2 weeks, the pattern observed from approximately 10 April through July in 1997 is similar to the pattern in 1981 and 1990.

\section{Discussion}

A combination of hydraulic conditions, remarkably similar in spring and early summer of 1981 and 1990, were potentially beneficial to recruitment of F. ebena in those years. First, despite a rapid April and May rise in lower Ohio River discharge in both years, there were brief periods of below-average discharge $\left(<7,000 \mathrm{~m}^{3} \mathrm{~s}^{-1}\right)$ in both early April and early May. Low discharge and associated low water velocity may enhance fertilization success by allowing sperm released into the water by males to be drawn into the mantle cavities of nearby females instead of being carried rapidly downstream (Downing and Downing 1992) 


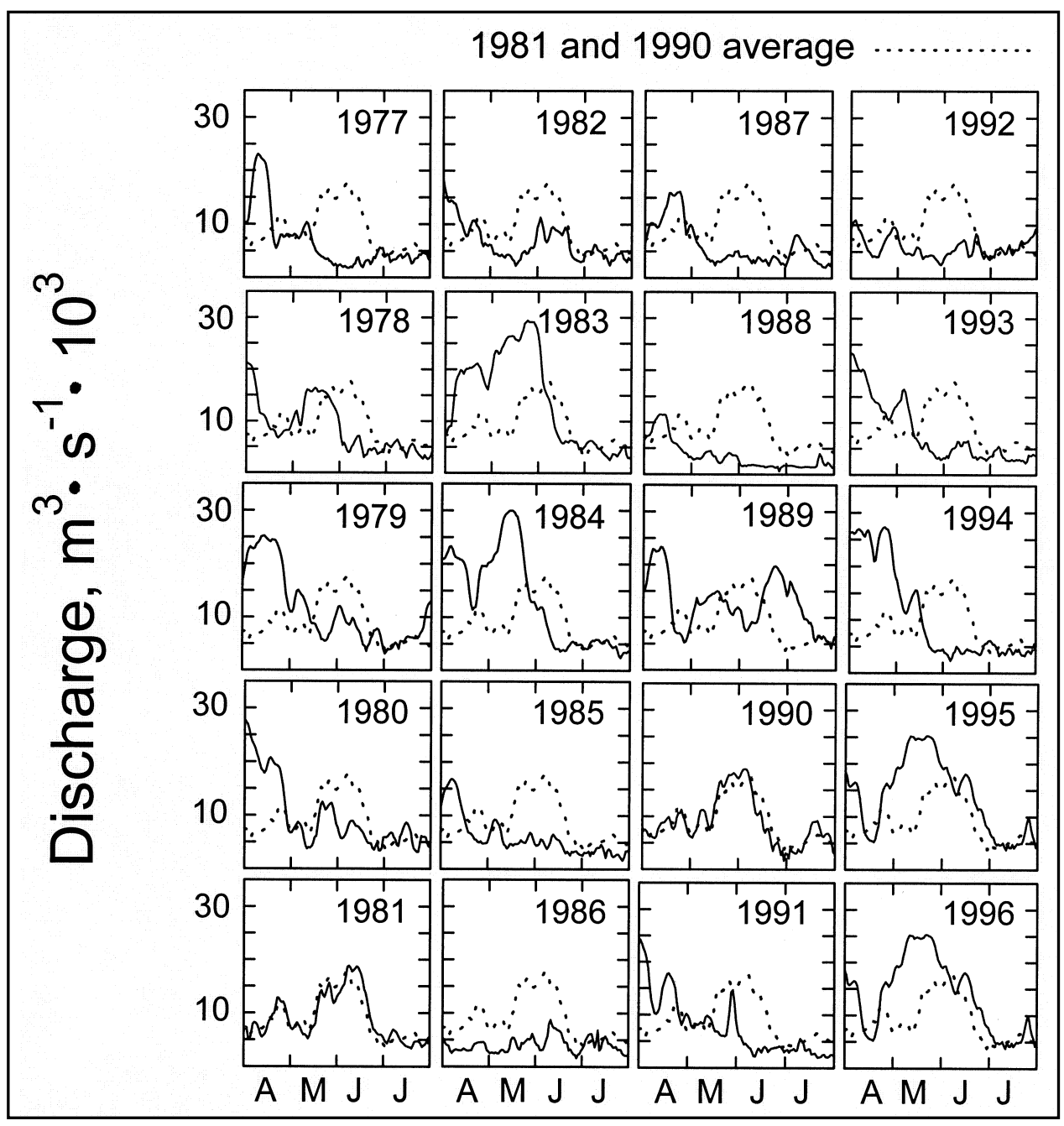

Figure 18. Discharge, lower Ohio River, April-July

Second, the rapid and large rise in lower Ohio River discharge from early May to early June (1990) or mid-June (1981) may have attracted spawning aggregations of $A$. chrysochloris to the gravelly shoal. In both years, this lower Ohio River rise was accompanied by a similar but earlier ending (mid-May to late May) rise in upper Mississippi River discharge; thus, there was no backwater effect of the upper Mississippi River on the lower Ohio River during this period. Based on water temperature the early May to June rise in lower Ohio River discharge in 1981 and 1990 precisely coincided with the period during which A. chyrsochloris were likely to have made spawning runs. In the Tennessee River, Wallus, Yeager, and Simon (1990) netted A. chrysochloris with flowing gametes over gravelly shoals in $16{ }^{\circ} \mathrm{C}$ water. Yolk-sac larvae of $A$. chrysochloris were collected at $21{ }^{\circ} \mathrm{C}$ in Alabama; peak densities of post yolk-sac larvae of A. chrysochloris occur in the Tennessee River usually in late May or early June (Wallus, Yeager, and Simon 1990 and references within). The lower Ohio River typically attains a temperature of $16{ }^{\circ} \mathrm{C}$ near the first of May and $21{ }^{\circ} \mathrm{C}$ by late May (Figure 17). During the spring temperature rise of $1981,16^{\circ} \mathrm{C}$ was attained by mid-April and $24{ }^{\circ} \mathrm{C}$ by early June. In 1990, temperature rose rapidly from 


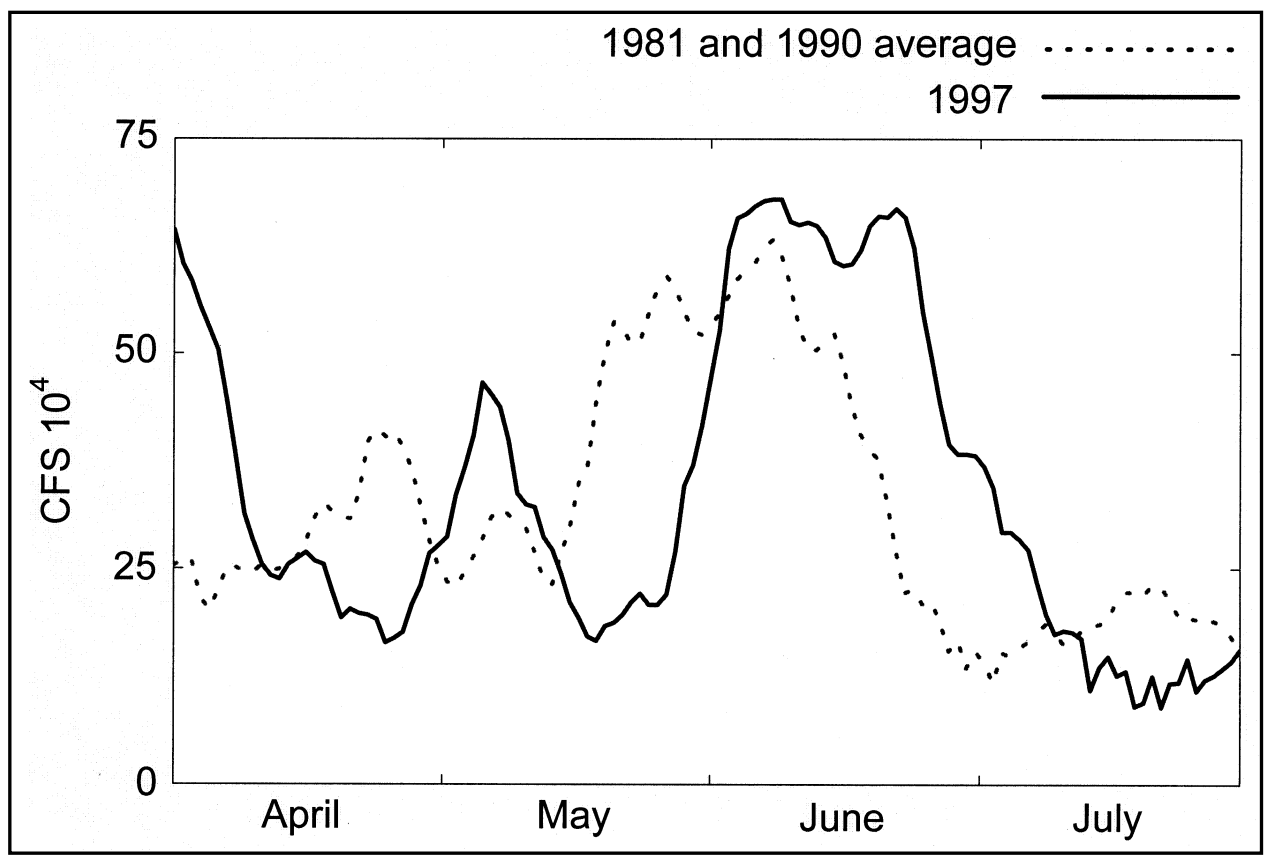

Figure 19. 1997 lower Ohio River discharge pattern

$12{ }^{\circ} \mathrm{C}$ in mid-April to $24{ }^{\circ} \mathrm{C}$ in mid-June. In addition to temperature requirements, spawning aggregations of $A$. chrysochloris are associated with high water velocity (Wallus, Yeager, and Simon 1990). Both water temperature and velocity were probably favorable for fish spawning aggregations during the rapid and large rise in lower Ohio River discharge in May to early June or mid-June. Wallus, Yeager, and Simon (1990) observed spawning of A chrysochloris over deeply submersed gravel $(7.3 \mathrm{~m})$ in the Tennessee River. Average depth over the lower Ohio River mussel bed was 6.4 to $7.0 \mathrm{~m}$ at the onset and 11.9 to $13.4 \mathrm{~m}$ at the end of the mid-spring to late spring rise in discharge in 1981 and 1990.

Third, the extremely rapid and great decline in lower Ohio River discharge from mid June to late June and early July in 1981 and 1990 created depositional conditions favorable to juvenile mussel settlement. It is also possible that depositional conditions allowed spent adult fish or recently hatched young-ofthe-year A. chrysochloris to remain over the mussel bed, enhancing opportunities both for glochidia attachment and local settlement of metamorphosed juveniles. The short duration of the transition from erosional to depositional conditions in June of both 1981 and 1990 resembles the average parasitic lifespan of $F$. ebena glochidia. The timing was coincident with the probable seasonal peak of glochidia release and juvenile settlement. Howard (1914), based on limited data, estimated a 23-day parasitic period for $F$. ebena glochidia. A 2-week period is more likely based on studies of other tachytictic amblemines (Yeager and Neves 1986; Yokely 1972; Coker et al. 1921). With respect to timing of glochidia release, Yokely (1972) observed that a very similar species in a nearby geographic location, Pleurobema cordatum in the Tennessee River near Florence, AL, begins to release glochidia in late April, with peak release in June. He estimated that temperatures greater than $21{ }^{\circ} \mathrm{C}$ were required for glochidia to mature in the mussel gill marsupia. In general, peak population release of 
glochidia by tachytictic amblemines tends to occur soon after temperature rise above $20^{\circ} \mathrm{C}$ - typically in late spring to early summer (Yeager and Neves 1986 ; Yokely 1972; Coker et al. 1921).

Thus, the successive rise and decline in lower Ohio River discharge in late spring and early summer were rapid enough to enhance both aggregation of spawning fish via high water velocity and juvenile mussel settlement via low water velocity. Furthermore, seasonal timing was appropriately coincident with probable peaks in both $A$. chrysochloris spawning and release of $F$. ebena glochidia. The much greater discharge of the upper Mississippi River relative to the lower Ohio River in late June and early July further enhanced depositional conditions in the lower Ohio River. The backwater effect of the upper Mississippi River on the lower Ohio River during this period may have further encouraged successful settlement of juvenile $F$. ebena.

Hydraulic conditions do not have to benefit $F$. ebena fertilization, aggregation of host fish, and successful settlement of juveniles to benefit recruitment of juveniles in a particular year. Some benefit may accrue if any one of these three processes is enhanced. Probably of greatest importance are host fish aggregation and juvenile settlement; fertilization tends to be successful even when recruitment is not (Bauer 1988). Fertilization probably benefits from both reduced water velocity in the boundary layer, regardless of general hydraulic conditions, and mussel population density. Nonetheless, hydraulic conditions of April through July of both 1981 and 1990 were appropriate in nature and timing to have conceivably benefited every aspect of $F$. ebena reproduction. Considered in light of the extraordinarily successful recruitment of 1981 and 1990, the complex and precisely matched hydraulic conditions of those two years seems more than circumstantial. It is noteworthy that 1997 hydraulic conditions, while not as closely matched as in 1981 and 1990, were nonetheless similar to those two years with strong $F$. ebena recruitment. Albeit minor compared with 1981 and 1990, moderate strength of a 1997 year class of $F$. ebena was evident in 1999.

Specific hydraulic conditions benefiting early survival were associated with the highly successful recruitment of $F$. ebena in the hydraulically dynamic lower Ohio River. However, other factors must play a role as well, especially relative mussel and fish density (Kat 1984). Abundance of adult mussels has been positively correlated with successful parasitism of host fish based on interpopulation comparisons of Margaritefera margaritifera in several central European rivers (Bauer 1988). However, the extraordinary annual variation in recruitment success observed in the present study was within a single population. Such temporal variation within a population of long-lived individuals suggests a primary cause other than an effect of adult mussel density on successful parasitism. Local abundance of glochidia hosts can be affected not only by aggregated spawning of $A$. chrysochloris but also by annual variation in the abundance of this fish in the lower Ohio River. However, with a lifespan of approximately 5 years (Wallus, Yeager, and Simon 1990), the strength of a particular year class of A. chrysochloris is not likely to account for exceptionally strong $F$. ebena recruitment in 1981 and 1990. Such an effect of a single fish year class would be more likely if young fish rapidly acquired and maintained immunity to glochidia infestation, thus making young fish the principal glochidia 
host (Bauer and Vogel 1987). However, adult A. chyrsochloris are known to host F. ebena glochidia (Surber 1913).

The survivorship curve developed for the 1981 cohort indicates that only 4 percent of 2-year-old mussels survive to age 18 years and an average length of $76 \mathrm{~mm}$. The largest individuals collected averaged $85 \mathrm{~mm}$ from 1983 to 1999. These individuals represent the minute fraction of the population that have extraordinary longevity, above-average growth, or a combination of these traits. Maximum longevity must be distinguished from average longevity. Certainly, survival to age 18 years has been uncommon for individuals of the 1981 cohort.

The dominance of the 1981 and 1990 cohorts of F. ebena in the lower Ohio River offered a rare opportunity to directly assess length-to-age relationships in a long-lived unionid species residing in a mainstream shoal of a large river. Not surprisingly, age-to-size relationships for long-lived species of freshwater mussels are based mainly on short-term studies that rely on the distance between annual growth rings in the shell (e.g., Coon, Eckblad, and Trygstad 1977; Chamberlain 1931). However, distinguishing annual from other significant interruptions of shell growth is somewhat subjective, difficult, and prone to error (Rhoads and Lutz 1980), especially in species such as F. ebena with slow adult growth, massive shells, and a dark periostracum (Coker et al. 1921). Mark and recapture as well as cage studies have been used to assess growth in such species (Coker et al. 1921) but are difficult to successfully complete in open channels of large rivers.

The authors' survivorship model for the 1981 year class of $F$. ebena from age 2 through 18 years is the first such model based on long-term monitoring of a single cohort of a long-lived riverine unionid. According to this model, a constant proportion (18.7 percent) of the cohort survived from year $\mathrm{x}$ to year $\mathrm{x}+$ 1. Thus, the probability of dying was independent of age within this portion of the lifespan. Bauer (1988) compared ages of living and dead M. margaritifera using annual growth lines in the hinge ligament and derived survivorship curves for mussel populations from central European rivers ranging from eutrophic to oligotrophic. Cultural eutrophy was correlated with mortality rate. Survivorship curves ranged from one similar in shape to that of $F$. ebena in the lower Ohio River (at eutrophic sites) to a convex curve (at oligotrophic sites) in which nearly all adults survived to very old age and then died within a few years. The former curve is common in animal populations, falling between the extremes of heavy concentration of death at the onset or end of the lifespan (McNaughton and Wolf 1973). Indeed, survivorship of $F$. ebena in the lower Ohio River from age 2 through 18 years is remarkably similar, both qualitatively and quantitatively, to survivorship of herring gulls on an island in Maine (McNaughton and Wolf 1973 and references within). A constant proportion (approximately 20 percent) of gulls died each year from age 2 to 17 years; thus, like $F$. ebena, only a small fraction survived beyond age 17 years.

Like most survivorship curves, the authors' was not based on the entire lifespan owing to the extreme difficulty of assessing larval and early juvenile mortality. A single adult female, depending on species and size, releases approximately 75,000 to 5 million glochidia in a reproductive season (Bauer 1988; Neves and Widlak 1988; Yeager and Neves 1986; Kat 1984; Young and 
Williams 1984; Coker et al. 1921). Nearly all mortality occurs very early in the lifespan; extremely high fecundity is required to balance high mortality of glochidia and settling juveniles. Thus, even a small increase in percent survival in the very early life stages can translate into long-term dominance of a particular year class.

Extraordinary recruitment success of $F$. ebena in only 2 years during a period of approximately two decades is remarkably similar to results of a classic study of the age composition of herring (Clupea harengus) catches in the Atlantic off Norway from 1907 through 1926 (Russell and Yonge 1975; Hardy 1965). Norwegian herring were dominated by just two year classes (1904 and 1914) during 20 years of monitoring. The life history of Norwegian herring and $F$. ebena in the lower Ohio River are basically similar in several respects. Longevity is similar. The 1904 year class of herring died out by 1924; most of the 1981 year class of F. ebena was dead by 1998. Sexual maturity is reached early enabling individuals to reproduce for many years. Finally, both populations are characterized by extremely high mortality in their early life history. Early life in both cases involves little protection from harsh physical and biological forces in open aquatic environments. Loss of eggs, yolk-sac larvae, and early juvenile stages is undoubtedly the greatest source of mortality to herring, a species that broadcasts eggs over spawning grounds in the open sea. Presumably, biological predation and shortage of the right planktonic food pose great risk to eggs and young herring (Hardy 1965). Glochidia and early juvenile $F$. ebena are susceptible to similarly high mortality from physical forces in hydraulically dynamic main channels of large rivers in addition to predation and other biological factors.

In populations of long-lived and highly iteroparous animals, such as $C$. harengus or F. ebena, favorable conditions for early survival can cause a few year classes to heavily dominate for many years. Much like the 1904 and 1914 year classes of C. harengus in the Atlantic off Norway from 1907 through 1928, the 1981 and 1990 year classes dominated the lower Ohio River population of F. ebena from 1983 through 1998. Hydraulic conditions in the lower Ohio River from April through July of both years were remarkably similar and appropriate for enhanced recruitment. Infrequent but occasionally very strong recruitment may be characteristic of unionid populations in relatively unregulated reaches of large rivers - once a common but now rare habitat of mussels in North America. 


\section{Future Considerations}

Personnel of the Environmental Laboratory, Vicksburg, MS, U.S. Army Engineer Research and Development Center, have used qualitative and quantitative methods to collect bivalves in the lower Ohio River since 1983. Results indicate that mussel beds of the lower Ohio River remain characterized by high richness, heavy dominance of $F$. ebena, good recruitment rates of juveniles (albeit annually quite variable), and resilience to nonindigenous species invasions. Growth rates of $F$. ebena have been lower at sites with high versus low infestations of $D$. polymorpha. However, native mussel populations remain abundant with the exception of Truncilla donaciformis and T. truncata-species in which maximum adult size is small and lifespan is short. The resilience of most unionids may be a consequence of the inability, thus far, of zebra mussels to establish sustained high density populations. However, the mussel bed clearly was resilient to long-term high density of $C$. fluminea (from approximately 1958 to the late 1980's). Fusconaia ebena was once the dominant thick-shelled unionid of stable river shoals throughout the lower Ohio River and the upper Mississippi River. In the lower Ohio River its dominance has corresponded with other indicators of a healthy community, including high richness, resilience, recruitment, and presence of an endangered species. These traits all suggest that mussel beds of the lower Ohio River remain among the most ecologically valuable and interesting in the nation.

River hydraulic conditions are important with respect to the location of mussel beds and patterns of annual recruitment in the lower Ohio River. The nearshore limit of the mussel bed at Olmsted closely coincides with sustained periods of low water. Because most unionids are long-lived, river stage must be considered over a few decades rather than just a few years to reveal this relationship. Similarly, long-term analysis of data revealed an apparent relationship between river discharge pattern from April through July and recruitment of $F$. ebena. Two years with exceptionally strong recruitment, 1981 and 1990, were remarkably closely matched with respect to hydraulic conditions that may have benefited both the probability of successful attachment of glochidia to fish gills and subsequent settlement of juveniles from fish. The discharge pattern of April through July 1981 and 1990 was somewhat similar to patterns in both 1995 and 1997. Both recent years supported moderate F. ebena recruitment.

Continued monitoring using qualitative and quantitative methods will provide data that can be used to determine if construction and operation of the Olmsted Locks and Dam project has negative effects on the mussels of the lower 
Ohio River. Long-term data have proven invaluable for interpreting causes and significance of fluctuations in physical and biological parameters, including population and community demographics and abundance of nonindigenous species. 


\section{References}

Bauer, G. (1988). "Threats to the freshwater pearl mussel Margaritifera margaritifera L. in central Europe," Biol. Conserv. 45, 239-253.

Bauer, G., and Vogel, C. (1987). "The parasitic stage of the freshwater pearl mussel, I. Host responses to glochidiosis," Arch. Hydrobiol. Suppl. 76, 393-402.

Chamberlain, T. K. (1931). "Annual growth of freshwater mussels," Bull. U.S. Bur. Fish. 46, 713-739.

Coker, R. E. (1914). "Water-power development in relation to fishes and mussels of the Mississippi," Document No. 805, U.S. Department of the Interior, Washington, DC, Bureau of Fisheries, Appendix VIII, 28 pp.

Coker, R. E., Shira, A. F., Clark, H. W., and Howard, A. D. (1921). "Natural history and propagation of fresh-water mussels," Bull. U.S. Bur. Fish. 37, 75-182.

Coon , T. G., Eckblad, J. W., and Trygstad, P. M. (1977). "Relative abundance and growth of mussels (Mollusca: Eulamellibranchia) in pools 8, 9 and 10 of the Mississippi River," Freshwater Biol. 7, 279-285.

Cummings, K. S., and Mayer, C. A. (1992). "Field guide to freshwater mussels of the Midwest," Manual 5, Illinois Natural History Survey, Champaign, IL, $194 \mathrm{pp}$.

Downing, J. A., and Downing, W. L. (1992). "Spatial aggregation, precision, and power in surveys of freshwater mussel populations," Can. J. Fish. Aquat. Sci. 49, 985-991.

Etnier, D. A., and Starnes, W. C. (1993). The fishes of Tennessee. The University of Tennessee Press, Knoxville, TN. 681 pp.

Hardy, A. (1965). The open sea: its natural history. Part II: fish and fisheries. Houghton Mifflin Company, Boston, 322 pp.

Howard, A. D. (1914). "Experiments in propagation of fresh-water mussels of the Quadrula group," Document No. 801, U.S. Department of the Interior, Washington, DC, Bureau of Fisheries, Appendix IV, 52 pp. 
Kat, P. W. (1984). "Parasitism and the Unionacea (Bivalvia)," Biol. Rev. 59, 189-207.

Lee, D. S., Gilbert, C. R., Hocutt, C. H., Jenkins, R. E., McAllister, D. E., and Stauffer, J. R., Jr. (1980). Atlas of North American freshwater fishes. Publication 1980-12, North Carolina State Museum of Natural History, Raleigh, 854 pp.

McMahon, R. F. (1983). "Ecology of an invasive pest bivalve, Corbicula fluminea," The Mollusca, Vol. 6, Ecology. W. D. Russell-Hunter, ed., Academic Press, Orlando, FL, 505-561.

McNaughton, S. J., and Wolf, L. L. (1973). General ecology. Holt, Rinehart and Winston, New York, 710 pp.

Miller, A. C., and Payne, B. S. (1988). "The need for quantitative sampling to characterize size demography and density of freshwater mussel communities," Bulletin of the American Malacological Union, Inc., 6, 49-54.

. (1991). "Co-occurrence of native freshwater mussels (Unionidae) and the non-indigenous Corbicula fluminea at two stable shoals in the Ohio River, U.S.A.," Malacological Review 27, 87-97.

. (1992). "Characterization of a freshwater mussel (Unionidae) community immediately downriver of Kentucky Lock and Dam in the Tennessee River," Trans. Ky. Acad. Sci., 53:154-161.

Miller, A. C., Payne, B. S., and Siemsen, T. (1986). "Description of the habitat of the endangered mussel Plethobasus cooperianus," The Nautilus 100, 14-18.

Neff, S. E., Pearson, W. D., and Holdren, G. C. (1981). "Aquatic and terrestrial communities in the lower Ohio River (RM 930-981)," Contract Report submitted to the U.S. Army Engineer District, Louisville, Louisville, KY.

Neves, R. J., and Widlak, J. C. (1988). "Occurrence of glochidia in stream drift and on fishes in the upper North Holston River, Virginia," Am. Midl. Nat. $112,111-120$.

Payne, B. S., and Miller, A. C. (1987). "Effects of current velocity on the freshwater bivalve Fusconaia ebena," Bulletin of the American Malacological Union, Inc., 5, 177-179.

. (1989). "Growth and survival of recent recruits to a population of Fusconaia ebena (Bivalvia: Unionidae) in the lower Ohio River," American Midland Naturalist 121, 99-104.

. (1997). "Spatial distribution of mussels at a bed in the lower Ohio River near Olmsted, Illinois," Technical Report EL-97-3, U.S. Army Engineer Waterways Experiment Station, Vicksburg, MS. 
Payne, B. S., and Miller, A. C. (1998). “An evaluation of freshwater mussels in the lower Ohio River in relation to the Olmsted Locks and Dam Project: 1995, 1996, and 1997 studies," Technical Report EL-98-12, U.S. Army Engineer Waterways Experiment Station, Vicksburg, MS.

. (1999). "An evaluation of freshwater mussel beds in the lower Ohio River in relation to the Olmsted Locks and Dam Project: 1998 studies," Technical Report EL-99-14, U.S. Army Engineer Waterways Experiment Station, Vicksburg, MS.

. (2000). "Recruitment of Fusconaia ebena (Bivalvia: Unionidae) in relation to discharge of the lower Ohio River," American Midland Naturalist $144,328-341$.

Payne, B. S., Miller, A. C., and Shafer, D. (1994). "An analysis of freshwater mussels (Unionidae) in the lower Ohio River at two beds near Olmsted, Illinois: 1992 studies," Technical Report EL-94-2, U.S. Army Engineer Waterways Experiment Station, Vicksburg, MS.

Pileou, E. C. (1969). An introduction to mathematical ecology. John Wiley, New York.

Rhoads, D. C., and Lutz, R. A., ed. (1980). "Skeletal growth of aquatic organisms," Biological records of environmental change. Plenum Press, New York, $750 \mathrm{pp}$.

Robinson, H. W., and Buchanan, T. M. (1988). Fishes of Arkansas. University of Arkansas Press, Fayetteville, AR, 536 pp.

Russell, F. S., and Yonge, M. (1975). The seas: An introduction to life in the sea. Frederick Warne, London, 283 pp.

Sinclair, R. M., and Isom, B. G. (1961). "A preliminary report on the introduced Asiatic clam Corbicula in Tennessee," Tennessee Stream Pollution Control Board, Tennessee Department of Public Health, Nashville, TN.

Surber, T. (1913). "Notes on the natural hosts of fresh-water mussels," Bull. U.S. Bur. Fish. 32, 101-116.

Taylor, R. W. (1989). "Changes in freshwater mussel populations of the Ohio River: 1,000BP to recent times," Ohio Journal of Science 89, 188-191.

Theler, J. L. (1987). "Prehistoric freshwater mussel assemblages of the Mississippi River in southwestern Wisconsin,” Nautilus 101, 143-150.

U.S. Army Engineer District, Louisville. (1991). "Draft Supplement I, Final environmental impact statement for the replacement of Locks and Dams 52 and 53 (Olmsted Locks and Dams), Lower Ohio River, IL-KY," Louisville, KY. 
U.S. Fish and Wildlife Service. (1991). "Endangered and threatened wildlife and plants," Federal Register, July 15, 1991, 50 CFR 17.11 and 17.12.

Wallus, R., Yeager, B. L., and Simon, T. P. (1990). "Reproductive biology and early life history of fishes in the Ohio River drainage, Volume 1:

Acipenseridae through Esocidae," Tennessee Valley Authority, Chattanooga, TN, $273 \mathrm{pp}$.

Williams, J. C. (1969). "Mussel fishery investigations, Tennessee, Ohio and Green rivers," Project Completion Report for Investigations Projects Under the Commercial Fisheries Research and Development Act of 1964, U.S. Fish and Wildlife Service and Kentucky Department of Fish and Wildlife Resources, Frankfort, KY.

Williams, J. C., and Schuster, G. A. (1982). "Freshwater mussel investigations in the Ohio River Mile 317.0 to Mile 981.0," A report submitted to the Department of Fish and Wildlife Resources, Division of Fisheries, Frankfort, KY.

Yeager, B. L., and Neves, R. J. (1986). "Reproductive cycle and hosts of the rabbit's foot mussel, Quadrula cylindrica strigillata (Mollusca: Unionidae) in the upper Tennessee River drainage," Am. Midl. Nat. 116, 329-340.

Yokely, P., Jr. (1972). "Life history of Pleurobema cordatum (Rafinesque 1820) (Bivalvia: Unionacea)," Malacologia, 11, 351-364.

Young, M., and Williams, J. (1984). "The reproductive biology of the freshwater pearl mussel Margaritifera margaritifera (Linn.) in Scotland. I. Field studies," Archiv fur Hydrobiologie 99, 405-422. 


\section{REPORT DOCUMENTATION PAGE}

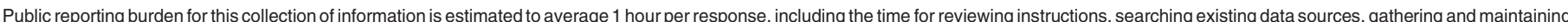

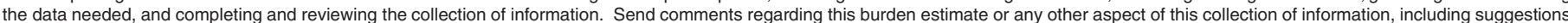

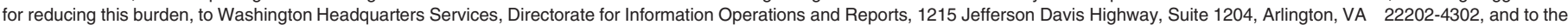
Office of Management and Budget, Paperwork Reduction Project (0704-0188), Washington, DC 20503.
1. AGENCY USE ONLY (Leave blank)
2. REPORT DATE July 2001
3. REPORT TYPE AND DATES COVERED
Final report

\section{TITLE AND SUBTITLE}

Status of Freshwater Mussels in the Lower Ohio River in Relation to the Olmsted Locks and Dam Project: 1999 Studies

6. AUTHOR(S)

Barry S. Payne, Andrew C. Miller

\section{FUNDING NUMBERS}

7. PERFORMING ORGANIZATION NAME(S) AND ADDRESS(ES)

U.S. Army Engineer Research and Development Center

Environmental Laboratory

3909 Halls Ferry Road, Vicksburg, MS 39180-6199
8. PERFORMING ORGANIZATION REPORT NUMBER

ERDC/EL TR-01-12

9. SPONSORING/MONITORING AGENCY NAME(S) AND ADDRESS(ES)

U.S. Army Engineer District, Louisville

10. SPONSORING/MONITORING AGENCY REPORT NUMBER

Louisville, KY 40202

\section{SUPPLEMENTARY NOTES}

12a. DISTRIBUTION/AVAILABILITY STATEMENT

Approved for public release; distribution is unlimited. 12b. DISTRIBUTION CODE

13. ABSTRACT (Maximum 200 words)

Surveys were conducted in late July and early August 1999 to assess community characteristics, population demography of dominant species, status of endangered species, and characteristics of nonindigenous populations of freshwater bivalves in the lower Ohio River (LOR). Data will be used to analyze ecological effects of construction and operation of a new lock and dam at River Mile (RM) 964.4. Primary focus has been on a prominent mussel bed just downstream of the project at Olmsted, IL.

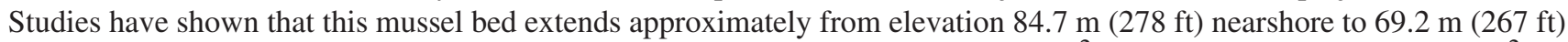
farshore (elevations referred to mean seal level). Moderate- (20-50 individuals per $\left.\mathrm{m}^{2}\right)$ or high- $\left(>50\right.$ individuals per $\left.\mathrm{m}^{2}\right)$ density assemblages of mussels tend to occur at more central elevations on the bed from approximately RM 966.4 to 968.3. The downstream and farshore limits of the mussel bed tend to be less distinct than the nearshore and upstream limits.

The community downstream of the project is extremely dominated by Fusconaia ebena. A mussel bed being monitored upstream of the project, at RM 957 near Post Creek, is clearly dominated by this species, but much less heavily than at Olmsted. Also, the abundance of F. ebena is higher farshore than nearshore at the Post Creek site. Communities at both Olmsted and Post Creek have been resilient to long-term occurrence (since approximately 1960) of the Asiatic clam,

(Continued)

14. SUBJECT TERMS

Freshwater mussels

Lower Ohio River

Olmsted Locks and Dam
Population demographics

Unionidae
15. NUMBER OF PAGES

49

16. PRICE CODE

\section{SECURITY CLASSIFICATION 18. SECURITY CLASSIFICATION 19. SECURITY CLASSIFICATION OF REPORT \\ UNCLASSIFIED \\ UNCLASSIFIED}




\section{3. (Concluded).}

Corbicula fluminea, and more recent occurrence of the zebra mussel, Dreissena polymorpha. Both mussel beds are characterized by extreme dominance of just two year classes, 1981 and 1990, of the dominant species.

Demographically complete sampling of F. ebena (Lea) at Olmsted was conducted from 1983 through 1999. Dominance of the 1981 and 1990 cohorts allowed length-to-age relationships to be estimated directly from length-frequency histograms. Two linear relationships adequately described growth rates from ages 2 through 17 years. The first applied to ages 2 through 10 years when annual growth averaged $6.0 \mathrm{~mm}$ per year. The second model applied to ages 10 through 17 years when annual growth averaged only $0.9 \mathrm{~mm}$ per year. A survivorship curve was based on density of the 1981 cohort from ages 2 through 17 years. During that period a constant proportion (17 percent) of the cohort died each year. Only 4 percent of the 1981 cohort in 1983 were still alive in 1999. Annual variation in hydraulic conditions related to recruitment success. In both 1981 and 1990 rapid and large spring rises in LOR discharge were immediately followed by similarly rapid and large declines. The rise coincided with the expected spawning peak of Alosa chrysochloris, the only fish host for F. ebena glochidia. The rapid return to low flow and depositional conditions was appropriately timed to enhance successful settlement of juvenile F. ebena after their parasitic stage on A. chrysochloris gills. 